\title{
Intercomparison of ILAS-II version 1.4 and version 2 target parameters with MIPAS-Envisat measurements
}

\author{
A. Griesfeller ${ }^{1, *}$, T. von Clarmann ${ }^{2}$, J. Griesfeller ${ }^{1, * *}$, M. Höpfner ${ }^{2}$, M. Milz ${ }^{2, * * *}$, H. Nakajima ${ }^{1}$, T. Steck ${ }^{2}$, T. Sugita ${ }^{1}$, \\ T. Tanaka ${ }^{1}$, and T. Yokota ${ }^{1}$ \\ ${ }^{1}$ National Institute for Environmental Studies (NIES), Tsukuba, Japan \\ ${ }^{2}$ Inst. für Meteorologie und Klimaforschung (IMK), Forschungszentrum Karlsruhe und Univ. Karlsruhe, Karlsruhe, Germany \\ * now at: Service d'Aéronomie, CNRS, Verrières-le-Buisson, France \\ *** now at: Laboratoire des Sciences du Climat et de l'Environnement CEA/CNRS/UVSQ-IPSL, Gif-sur-Yvette, France \\ *** now at: Institutionen för Rymdvetenskap, Luleå Tekniska Universitet, Kiruna, Sweden
}

Received: 21 May 2007 - Published in Atmos. Chem. Phys. Discuss.: 2 July 2007

Revised: 14 December 2007 - Accepted: 18 January 2008 - Published: 20 February 2008

\begin{abstract}
This paper assesses the mean differences between the two ILAS-II data versions (1.4 and 2) by comparing them with MIPAS measurements made between May and October 2003. For comparison with ILAS-II results, MIPAS data processed at the Institut für Meteorologie und Klimaforschung, Karlsruhe, Germany (IMK) in cooperation with the Instituto de Astrofísica de Andalucía (IAA) in Granada, Spain, were used. The coincidence criteria of $\pm 300 \mathrm{~km}$ in space and $\pm 12 \mathrm{~h}$ in time for $\mathrm{H}_{2} \mathrm{O}, \mathrm{N}_{2} \mathrm{O}$, and $\mathrm{CH}_{4}$ and the coincidence criteria of $\pm 300 \mathrm{~km}$ in space and $\pm 6 \mathrm{~h}$ in time for $\mathrm{ClONO}_{2}, \mathrm{O}_{3}$, and $\mathrm{HNO}_{3}$ were used. The ILAS-II data were separated into sunrise (= Northern Hemisphere) and sunset (= Southern Hemisphere). For the sunrise data, a clear improvement from version 1.4 to version 2 was observed for $\mathrm{H}_{2} \mathrm{O}, \mathrm{CH}_{4}, \mathrm{ClONO}_{2}$, and $\mathrm{O}_{3}$. In particular, the ILAS-II version 1.4 mixing ratios of $\mathrm{H}_{2} \mathrm{O}$ and $\mathrm{CH}_{4}$ were unrealistically small, and those of $\mathrm{ClONO}_{2}$ above altitudes of $30 \mathrm{~km}$ unrealistically large. For $\mathrm{N}_{2} \mathrm{O}$ and $\mathrm{HNO}_{3}$, there were no large differences between the two versions. Contrary to the Northern Hemisphere, where some exceptional profiles deviated significantly from known climatology, no such outlying profiles were found in the Southern Hemisphere for both versions. Generally, the ILAS-II version 2 data were in better agreement with the MIPAS data than the version 1.4, and are recommended for quantitative analysis in the stratosphere. For $\mathrm{H}_{2} \mathrm{O}$ data in the Southern Hemisphere, further data quality evaluation is necessary.
\end{abstract}

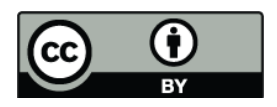

Correspondence to: T. Sugita (tsugita@nies.go.jp)

\section{Introduction}

Water vapor $\left(\mathrm{H}_{2} \mathrm{O}\right)$, nitrous oxide $\left(\mathrm{N}_{2} \mathrm{O}\right)$, methane $\left(\mathrm{CH}_{4}\right)$, ozone $\left(\mathrm{O}_{3}\right)$, nitric acid $\left(\mathrm{HNO}_{3}\right)$, and chlorine nitrate $\left(\mathrm{ClONO}_{2}\right)$ are trace species that play an important role in global warming, greenhouse effect, and ozone-depletion processes in the lower stratosphere. These trace gases have been observed in the high latitudes and on a global scale in 2003 respectively by two satellite borne instruments, the Improved Limb Atmospheric Spectrometer-II (ILAS-II) (Nakajima et al., 2006a) and the Michelson Interferometer for Passive Atmospheric Sounding (MIPAS) (Fischer et al., 2007). ILAS-II was designed to monitor vertical profiles of ozone and related minor species to study the ozone layer (Nakajima et al., 2006a). The first public release of the data was version 1.4 (V1.4), including $\mathrm{O}_{3}, \mathrm{HNO}_{3}, \mathrm{~N}_{2} \mathrm{O}$, and $\mathrm{CH}_{4}$ (Ejiri et al., 2006; Irie et al., 2006; Sugita et al., 2006; Wetzel et al., 2006). The validation studies showed that there were negative biases of the $\mathrm{H}_{2} \mathrm{O}, \mathrm{CH}_{4}$, and $\mathrm{O}_{3}$ data in the Northern Hemisphere (NH) measurements, although no major biases were found in the Southern Hemisphere ( $\mathrm{SH}$ ) measurements. The $\mathrm{H}_{2} \mathrm{O}$ data in the NH especially showed in some exceptional cases profiles that deviate from known climatology, thus they are not open to the public. In order to consider this problem, we have developed a new retrieval algorithm, version 2 (V2). This paper assesses the mean differences between the two ILAS-II data versions (1.4 and 2) by comparing them with MIPAS measurements made between May and October 2003. In Sect. 2, we report the instrumental details of ILAS-II and MIPAS that are necessary to understand the intercomparison. In Sect. 3, we present the vertical profiles derived from the data of ILAS-II and MIPAS between May and October 2003 on a monthly basis. Hemispheric differences are investigated in detail, and clear improvements in the ILAS-II V2 data are shown in Sect. 4. We conclude the characteristics of ILAS-II V2 dataset in Sect. 5.

Published by Copernicus Publications on behalf of the European Geosciences Union. 


\section{Measurements and data analysis}

\subsection{ILAS-II}

The ILAS-II solar occultation instrument was developed under responsibility of the Ministry of the Environment (MOE) of Japan to succeed the ILAS. It was launched in December 2002 on board the Advanced Earth Observing SatelliteII (ADEOS-II) spacecraft of the Japan Aerospace Exploration Agency (JAXA) (Nakajima et al., 2006a) and operated during its sun-synchronous polar orbit at an inclination angle of $98.7^{\circ}$ and a height of $802.9 \mathrm{~km}$. Measurements were made approximately 14 times a day in each hemisphere from January to October 2003. The instantaneous field of view (IFOV) for the infrared (IR) spectrometer at the tangent point was $1.0 \mathrm{~km}$ in the vertical and $13.0 \mathrm{~km}$ in the horizontal. ILAS-II included four observation channels. Three of them used the infrared region (IR: $850-1610 \mathrm{~cm}^{-1}$, MIR: $1754-3333 \mathrm{~cm}^{-1}$, and $778-782 \mathrm{~cm}^{-1}$ ), and one the visible (VIS: $12755-13280 \mathrm{~cm}^{-1}$ ). ILAS-II used a solar occultation technique from which vertical profiles of several atmospheric constituents can be retrieved. This includes: $\mathrm{O}_{3}$, $\mathrm{HNO}_{3}, \mathrm{NO}_{2}, \mathrm{~N}_{2} \mathrm{O}, \mathrm{CH}_{4}, \mathrm{H}_{2} \mathrm{O}, \mathrm{ClONO}_{2}, \mathrm{~N}_{2} \mathrm{O}_{5}, \mathrm{CFC}-11$, CFC-12, and aerosol extinction coefficients. Volume mixing ratio (VMR) profiles of atmospheric constituents are derived with an onion-peeling retrieval method (Yokota et al., 2002), with a retrieval vertical grid of $1 \mathrm{~km}$. Vertical resolutions were $1.3-2.9 \mathrm{~km}$ at tangent heights of $15-55 \mathrm{~km}$ (Nakajima et al., 2006a). The simultaneous retrieval of the species presented below was made using all of the 44 spectral elements of the IR spectrometer. The first public release of the data was V1.4, including $\mathrm{O}_{3}, \mathrm{HNO}_{3}, \mathrm{~N}_{2} \mathrm{O}$, and $\mathrm{CH}_{4}$ (Ejiri et al., 2006; Irie et al., 2006; Sugita et al., 2006; Wetzel et al., 2006). As mentioned in Sect. 1, the validation studies of V1.4 data showed several problems, especially in the $\mathrm{NH}$ data. Artefacts in the $\mathrm{NH}$ measurements are due to a degradation of output signals caused by a deformation of entrance slits of the instrument (Nakajima et al., 2006a). To overcome the difficulty presented by the ILAS-II hardware issues, a new retrieval algorithm, V2, was developed including a model for correcting the degraded transmittance, a more refined altitude registration method, and other minor revisions. The most important change was the inclusion of transmittance correction for the NH data (it was not included for the $\mathrm{SH}$, as described in the appendix). This and other differences are described in Appendix A. It should be noted that occultation events occurred in the $\mathrm{NH}$ and in the $\mathrm{SH}$ as observed by satellite sunrise and sunset measurements, respectively. To examine how the V2 data improved from the V1.4 data, we compared the ILAS-II data with measurements from MIPAS on board Envisat that are already validated, in the process of validation, or were at least compared to other measurements.

\subsection{MIPAS}

MIPAS, which was developed at the European Space Agency (ESA), is one of the atmospheric sounding instruments on board Envisat, launched in March 2002 (Fischer et al., 2007). It is an infrared spectrometer working in the range between $685 \mathrm{~cm}^{-1}$ and $2410 \mathrm{~cm}^{-1}(15 \mu \mathrm{m}$ and $4 \mu \mathrm{m})$ with a spectral resolution of $0.035 \mathrm{~cm}^{-1}$ (unapodized) in five spectral bands, which allow the retrieval of vertical profiles of numerous atmospheric constituents, including: $\mathrm{CH}_{4}, \mathrm{ClO}, \mathrm{ClONO}_{2}, \mathrm{CO}$, CFC-11, CFC-12, $\mathrm{H}_{2} \mathrm{O}, \mathrm{HNO}_{3}, \mathrm{HNO}_{4}, \mathrm{HOCl}, \mathrm{N}_{2} \mathrm{O}_{5}, \mathrm{~N}_{2} \mathrm{O}$, $\mathrm{NO}_{2}, \mathrm{NO}, \mathrm{O}_{3}$, and other trace gases, covering an altitude range from 6 to $68 \mathrm{~km}$. The orbit is sun-synchronous at $800 \mathrm{~km}$ altitude with an inclination of $98.55^{\circ}$, performing 14.4 orbits per day. The field of view is $30 \mathrm{~km}$ in the horizontal and $3 \mathrm{~km}$ in the vertical at the tangent points. The retrieval vertical grid was $1 \mathrm{~km}$, which is identical to the ILAS-II. While the operational ESA data are processed with a code described by Ridolfi et al. (2000), we used data from a science-oriented data processor, developed at IMK in cooperation with IAA. The data used for comparison are based on IMK spectra version $\mathrm{V} 3 \mathrm{O}$ and are based on calibrated radiance spectra generated by offline level-1 re-processing (ESA version IPF 4.61/4.62). The scientific data processor (von Clarmann et al., 2003a,b; Funke et al., 2001) has been developed and is operated by the IMK, Karlsruhe, Germany, in cooperation with the IAA in Granada, Spain, and uses the Karlsruhe Optimized and Precise Radiative transfer Algorithm (KOPRA) as a forward model for the retrieval (Höpfner et al., 1998; Stiller et al., 1998; Stiller, 2000). The MIPASIMK data have been chosen instead of the ESA data, because the ESA data do not cover all species considered in our intercomparison, particularly $\mathrm{ClONO}_{2}$ is missing in the ESA data set, the IMK data often cover a wider altitude range, often are less oscillatory, and use a more rigorous cloud rejection threshold. The spectroscopic database (Flaud et al., 2003) used for IMK MIPAS retrievals is largely identical to HITRAN 2004. MIPAS took measurements almost continuously from July 2002 until the end of March 2004. Instabilities in the interferometer driver velocity led to a temporary interruption of operational measurements at that point, but it was restarted with a different observation scheme in early 2005.

The retrieval strategies and quality assessment of the MIPAS data have already been published, for example, $\mathrm{H}_{2} \mathrm{O}$ (Milz et al., 2005), $\mathrm{O}_{3}$ (Steck et al., 2007; Bracher et al., 2005; Verronen et al., 2005; Wang et al., 2005), $\mathrm{N}_{2} \mathrm{O}$ and $\mathrm{CH}_{4}$ (Bracher et al., 2005; Glatthor et al., 2005), $\mathrm{HNO}_{3}$ (Mengistu Tsidu et al., 2005; Wang et al., 2007), and $\mathrm{ClONO}_{2}$ (Höpfner et al., 2004, 2007). However, these validation results are also based partly on different spectra versions, and retrieval baseline versions (e.g. different wavelength bands, regularization), and not only on the spectra generated by offline level-1 re-processing presented here. In contrast to the large spectral range in which the ILAS-II 
Table 1. Version number of the scientific processor of MIPAS.

\begin{tabular}{ll}
\hline Gas & Version number \\
\hline $\mathrm{H}_{2} \mathrm{O}$ & V3O_H2O_11 \\
$\mathrm{N}_{2} \mathrm{O}$ & V3O_N2O_8 \\
$\mathrm{CH}_{4}$ & V3O_CH4_8 \\
$\mathrm{O}_{3}$ & V3O_O3_7 \\
$\mathrm{HNO}_{3}$ & V3O_HNO3_7 \\
$\mathrm{ClONO}_{2}$ & V3O_ClONO2_11 \\
\hline
\end{tabular}

measurements were performed, the MIPAS retrievals use narrow wavelength bands called microwindows. For all gases the same spectroscopic dataset was used for MIPAS and for ILAS-II V2 data, so the spectroscopic error is not expected to contribute to the differences between ILAS-II and MIPAS results.

Table 1 shows the version number of the scientific processor of MIPAS for each gas. The MIPAS version identifiers are identical for Northern and Southern Hemispheres for each gas.

\section{Comparison}

\subsection{Coincidence criteria}

Using the coincidence criteria of $\pm 300 \mathrm{~km}$ in space and $\pm 12 \mathrm{~h}$ in time for the long-lived gases $\mathrm{H}_{2} \mathrm{O}, \mathrm{N}_{2} \mathrm{O}$, and $\mathrm{CH}_{4}$ and the coincidence criteria of $\pm 300 \mathrm{~km}$ in space and $\pm 6 \mathrm{~h}$ in time for $\mathrm{ClONO}_{2}, \mathrm{O}_{3}$, and $\mathrm{HNO}_{3}$, different numbers of coincidences were found for these gases as shown in Tables 2 and 3. These coincidence criteria were approximately the same as used for MIPAS validation studies (e.g., Höpfner et al., 2007; Steck et al., 2007; Wang et al., 2007) and they were chosen to provide a sufficiently large number of coincidences to obtain reasonably reliable statistics. The number of coincidences is different for each gas because MIPAS data from the scientific data processor were not always available for each gas. Besides the number of coincidences, the average distances in space and time for the northern and Southern Hemispheres are also listed in Tables 2 and 3, respectively.

Coincidences in both of the hemispheres were found between May and October 2003. According measurements were performed between $54.8^{\circ} \mathrm{N}$ and $71.0^{\circ} \mathrm{N}$ (ILAS-II) and $55.7^{\circ} \mathrm{N}$ and $72.4^{\circ} \mathrm{N}$ (MIPAS), and between $68.5^{\circ} \mathrm{S}$ and $87.8^{\circ} \mathrm{S}$ (ILAS-II) and $67.7^{\circ} \mathrm{S}$ and $86.6^{\circ} \mathrm{S}$ (MIPAS). The existence of polar vortex and hence the presence of polar stratospheric clouds (PSCs) was not considered in the NH. In the $\mathrm{SH}$, on the other hand, the coincidences were separated into those from inside and those from outside the polar vortex using the criterion of Nash et al. (1996) at an equivalent latitude of $550 \mathrm{~K}$. There were only six coincidences in May which were outside or at the edge of the polar vortex. All the other coincidences were clearly inside.

\subsection{Monthly averaged profiles}

Figures 1-6 show monthly averaged profiles of $\mathrm{H}_{2} \mathrm{O}, \mathrm{N}_{2} \mathrm{O}$, $\mathrm{CH}_{4}, \mathrm{O}_{3}, \mathrm{HNO}_{3}$, and $\mathrm{ClONO}_{2}$ in the $\mathrm{NH}$, and Figs. 7-12 show those in the SH. The ILAS-II V1.4 and V2 data were compared to the MIPAS data as a global validation source. Hemispheric averaged profiles were also depicted for each figure. The number of coincidences is shown in each panel. Most of the coincidences were found from August to October in the $\mathrm{NH}$, and in September and October in the $\mathrm{SH}$.

For $\mathrm{H}_{2} \mathrm{O}, \mathrm{CH}_{4}$, and $\mathrm{ClONO}_{2}$ in the $\mathrm{NH}$, the comparison between MIPAS and both versions of ILAS-II suggest a clear improvement in the later version, owing to the inclusion of transmittance corrections. Unlike the ILAS-II V1.4 NH data, there were no large differences between ILAS-II V1.4 and $\mathrm{V} 2$ data in the SH, because the ILAS-II V1.4 SH data did not have the difficulty as was found in the NH. Detailed discussion on this point will be given in Sect. 4 .

Some distinctive features are briefly mentioned. In Fig. 7, it can be seen that there was a clear maximum peak of the MIPAS $\mathrm{H}_{2} \mathrm{O}$ mixing ratios around $30-35 \mathrm{~km}$ in the $\mathrm{SH}$ in May, subsiding in July to $25-30 \mathrm{~km}$, which did also exist in the ILAS-II data, with a small bias for ILAS-II V1.4 and a larger bias for V2. Below $20 \mathrm{~km}$, both instruments observed dehydrated air inside the polar vortex with very small VMR values of about 1-1.5 ppmv between August and October. Note that the number of coincidences for May (4) and July (15) are small compared to the other months and thus the shape of the mean profile may be dominated by an individual profile. The reason for the differences between MIPAS and ILAS-II might be the different retrieval approaches. While onion-peeling is used for ILAS-II a global-fit approach is used for MIPAS, which uses a smoothing constraint related to the shape of an a priori profile.

In SH October, clear ozone hole values ( $\leq 0.5 \mathrm{ppmv})$ below $20 \mathrm{~km}$ (Fig. 10) can be seen. $\mathrm{HNO}_{3}$ had a bi-modal altitude distribution seen by both instruments in SH July (Fig. 11). The large values in high altitudes in this bi-modal distribution were due to a high-altitude enhancement of $\mathrm{NO}_{\mathrm{x}}$, which was also seen by MIPAS (Stiller et al., 2005). The low values in the ILAS-II data for low altitudes could be the result of denitrification.

\subsection{Hemispheric averages and differences between ILAS- II and MIPAS}

Figures. 13-18 show the mean profiles of $\mathrm{H}_{2} \mathrm{O}, \mathrm{N}_{2} \mathrm{O}, \mathrm{CH}_{4}$, $\mathrm{O}_{3}, \mathrm{HNO}_{3}$, and $\mathrm{ClONO}_{2}$ for all coincidences in the $\mathrm{NH}$, and Figs. 19-25 show those in the $\mathrm{SH}$ except for $\mathrm{O}_{3}$ and $\mathrm{HNO}_{3}$. In the following we use a terminology, as suggested e.g. by von Clarmann (2006), who propose to first determine the bias, i.e. the mean difference, between two sets of 
Table 2. Coincidences of ILAS-II and MIPAS measurements in the NH. Different numbers of coincidences for the different gases are mainly caused by different coincidence criteria for inert gases on the one hand and reactive species on the other hand. Minor differences are due to occasional failure of convergence in some of the MIPAS retrievals.

\begin{tabular}{cccccc}
\hline Gas & $\begin{array}{c}\text { \# of } \\
\text { coinc. }\end{array}$ & $\begin{array}{c}\text { Average } \\
\Delta \text { space } \\
{[\mathrm{km}]}\end{array}$ & $\begin{array}{c}\text { Average } \\
\left.\Delta \text { lat. }{ }^{\circ}{ }^{\circ}\right]\end{array}$ & $\begin{array}{c}\text { Average } \\
\left.\Delta \text { long. }{ }^{\circ}{ }^{\circ}\right]\end{array}$ & $\begin{array}{c}\text { Average } \\
\Delta \text { time } \\
{[\text { hours }]}\end{array}$ \\
\hline $\mathrm{H}_{2} \mathrm{O}$ & 216 & 168 & -0.27 & -1.37 & $6: 11$ \\
& & \pm 84 & \pm 1.04 & \pm 3.05 & $\pm 2: 24$ \\
\hline $\mathrm{N}_{2} \mathrm{O}, \mathrm{CH}_{4}$ & 219 & 168 & -0.27 & -1.35 & $6: 11$ \\
& & \pm 83 & \pm 1.04 & \pm 3.04 & $\pm 2: 26$ \\
\hline $\mathrm{O}_{3}, \mathrm{HNO}_{3}, \mathrm{ClONO}_{2}$ & 118 & 167 & -0.29 & -1.92 & $4: 21$ \\
& & \pm 86 & \pm 1.05 & \pm 2.61 & $\pm 1: 21$ \\
\hline
\end{tabular}

Table 3. Same as in 2 but for the SH. The number in brackets indicate the number of coincidences inside the polar vortex.

\begin{tabular}{cccccc}
\hline Gas & $\begin{array}{c}\text { \# of } \\
\text { coinc. }\end{array}$ & $\begin{array}{c}\text { Average } \\
\Delta \text { space } \\
{[\mathrm{km}]}\end{array}$ & $\begin{array}{c}\text { Average } \\
\Delta \text { lat. }\left[^{\circ}\right]\end{array}$ & $\begin{array}{c}\text { Average } \\
\Delta \text { long. }\left[^{\circ}\right]\end{array}$ & $\begin{array}{c}\text { Average } \\
\Delta \text { time } \\
{[\mathrm{h}]}\end{array}$ \\
\hline $\mathrm{H}_{2} \mathrm{O}$ & 614 & 189 & 0.20 & 0.06 & $7: 22$ \\
& $(608)$ & \pm 68 & \pm 1.30 & \pm 17.52 & $\pm 3: 48$ \\
\hline $\mathrm{N}_{2} \mathrm{O}, \mathrm{CH}_{4}$ & 574 & 188 & 0.21 & 0.01 & $7: 25$ \\
& $(568)$ & \pm 68 & \pm 1.28 & \pm 17.78 & $\pm 3: 48$ \\
\hline $\mathrm{O}_{3}$ & 224 & 207 & -0.06 & -0.70 & $2: 58$ \\
& $(218)$ & \pm 54 & \pm 1.44 & \pm 15.06 & $\pm 1: 33$ \\
\hline $\mathrm{HNO}_{3}$ & 233 & 209 & -0.11 & -0.38 & $2: 58$ \\
& $(227)$ & \pm 54 & \pm 1.53 & \pm 15.34 & $\pm 1: 32$ \\
\hline $\mathrm{ClONO}_{2}$ & 205 & 211 & -0.06 & -0.60 & $3: 01$ \\
& $(199)$ & \pm 54 & \pm 1.42 & \pm 15.19 & $\pm 1: 36$ \\
\hline
\end{tabular}

measurements, to assess its significance by means of its standard error, and to use debiased measurements for subsequent precision validation. In our Figs. 13 to 25 the mean differences (ILAS-II - MIPAS) along with their statistical uncertainties, according to Eqs. (30) and (31) in von Clarmann (2006) are included. Also, the percentage difference is according to Eqs. (39) and (40) in von Clarmann (2006).

For the $\mathrm{SH} \mathrm{O}_{3}$ comparisons, data were separated in two periods; one is from May until September (Fig. 22), and the other is for October (Fig. 23) where a significant ozone depletion was seen in the lower stratosphere (a regular ozone hole condition). For the $\mathrm{SH} \mathrm{HNO}_{3}$ comparison, the July data were not considered in the analysis of differences because of the mesospheric $\mathrm{NO}_{x}$ transport into the stratosphere, as mentioned earlier.

\subsection{Tracer correlation and time series}

To evaluate the ILAS-II versions, we also examine a tracertracer correlation. Figures 26 and 27 show correlations between $\mathrm{N}_{2} \mathrm{O}$ and $\mathrm{CH}_{4}$ in the $\mathrm{NH}$ and $\mathrm{SH}$, respectively. A more compact correlation was found from V2 than from V1.4 in the $\mathrm{NH}$, although an almost identical correlation was found in the $\mathrm{SH}$.

Another way to evaluate them is to examine a time-series of species in different atmospheric conditions. Figure 28 shows an $\mathrm{O}_{3}$ time-series at $24 \mathrm{~km}$ in the $\mathrm{SH}$.

\section{Discussion}

\subsection{Northern Hemisphere}

Unrealistic small values of ILAS-II V1.4 $\mathrm{H}_{2} \mathrm{O}$ and $\mathrm{CH}_{4}$ data (Figs. 13 and 15) above 20-25 km were due to a degradation 

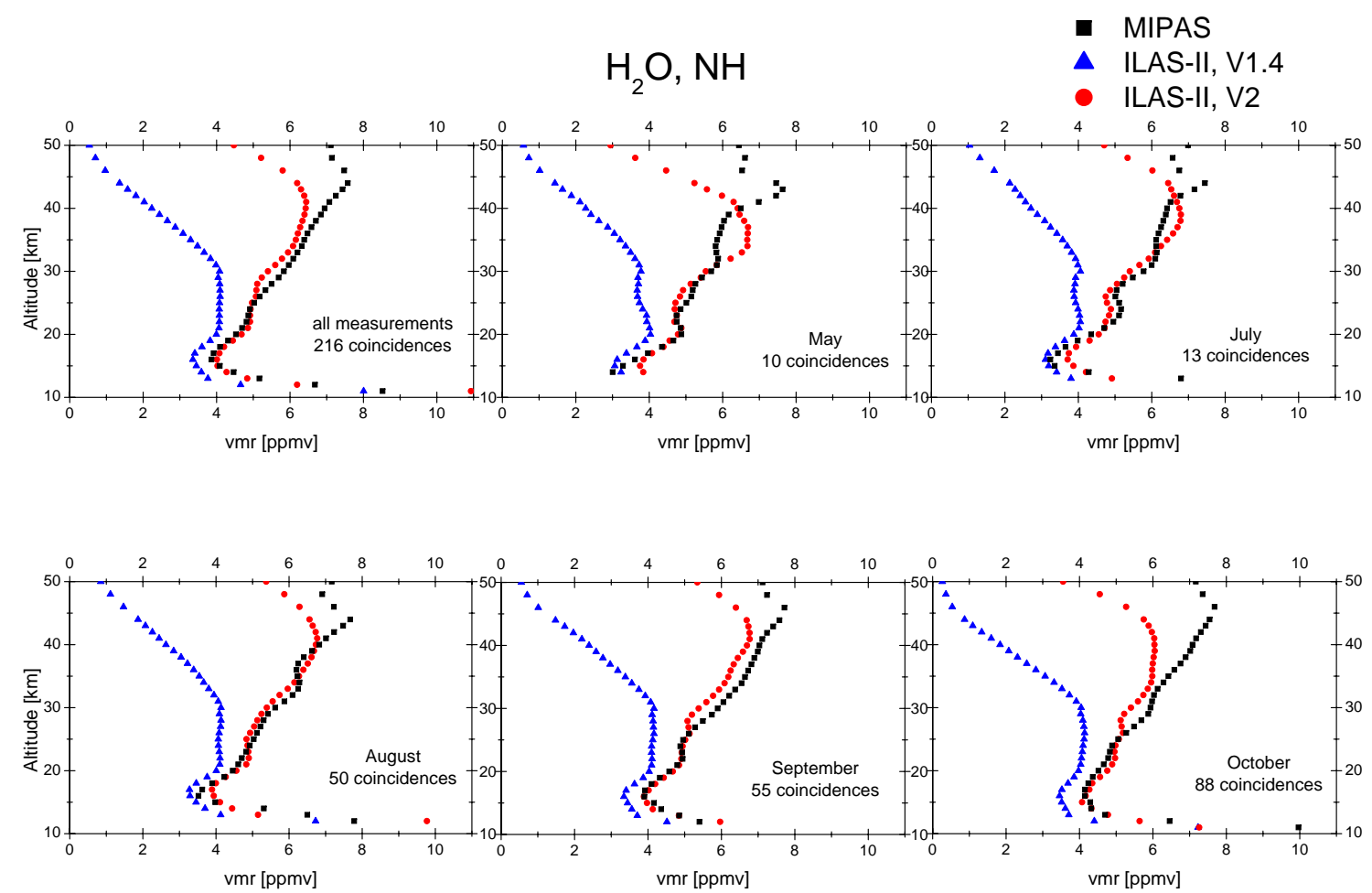

Fig. 1. Comparison of the $\mathrm{H}_{2} \mathrm{O}$ measurements in the NH. The mean profiles of the MIPAS measurements are shown as black squares, the mean profiles of the ILAS-II V1.4 data as blue triangles, and the mean profiles of the ILAS-II V2 data as red circles for each month in which we found coincidences.
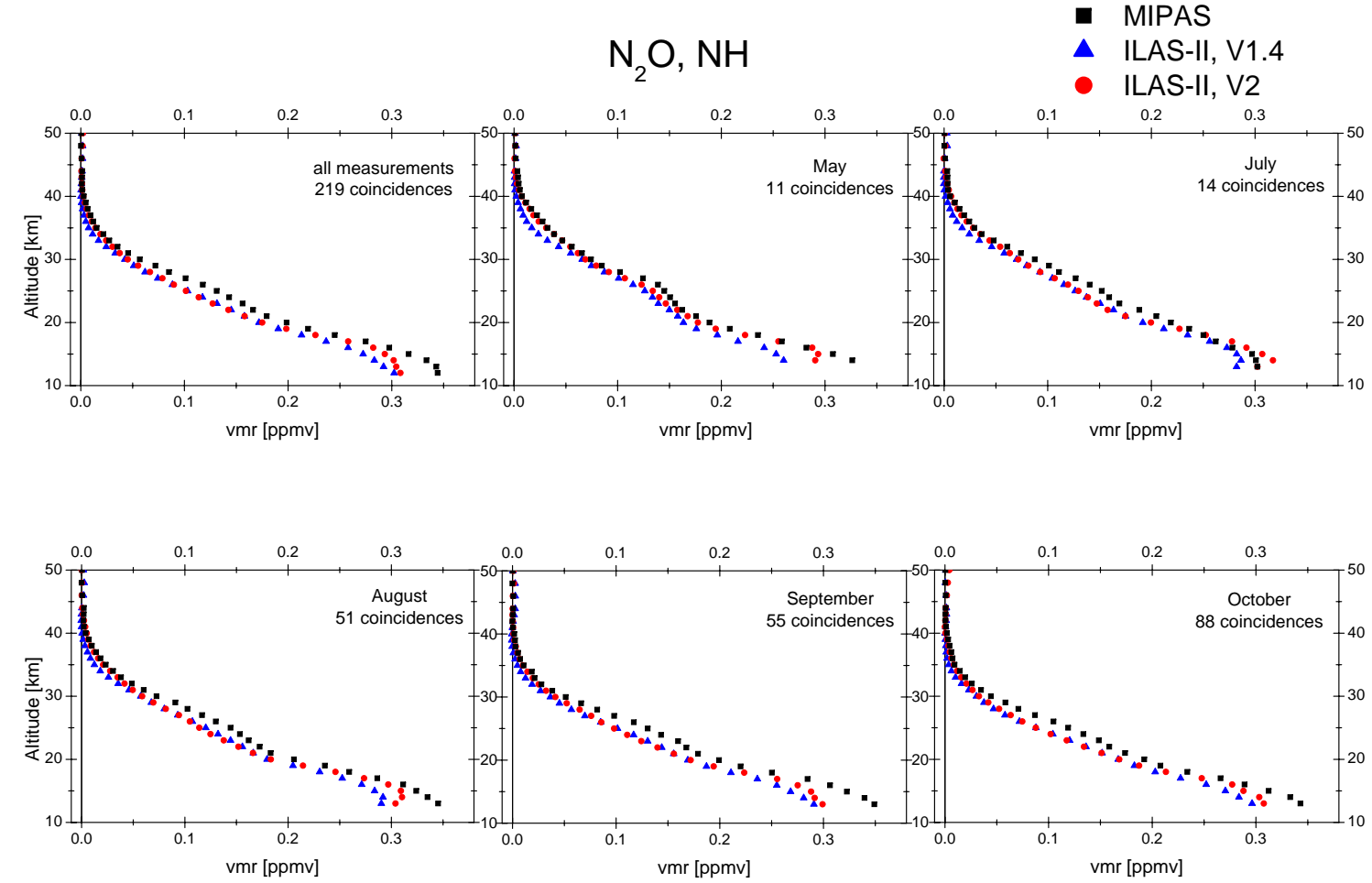

Fig. 2. As in Fig. 1 but for $\mathrm{N}_{2} \mathrm{O}$. 


\section{$\mathrm{CH}_{4}, \mathrm{NH}$}

- MIPAS
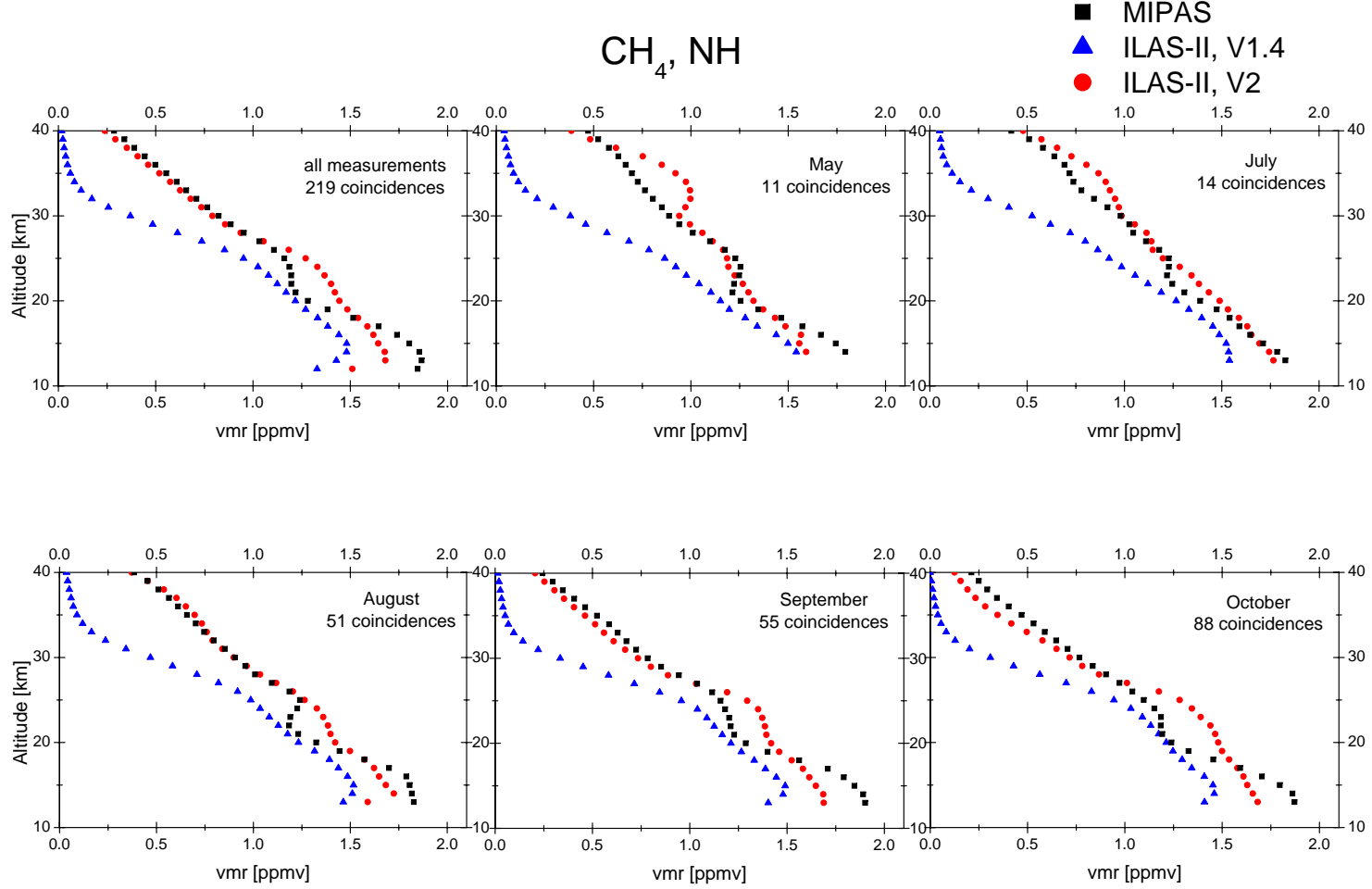

Fig. 3. As in Fig. 1 but for $\mathrm{CH}_{4}$.

- MIPAS

- ILAS-II, V1.4

- ILAS-II, V2

$\mathrm{O}_{3}, \mathrm{NH}$
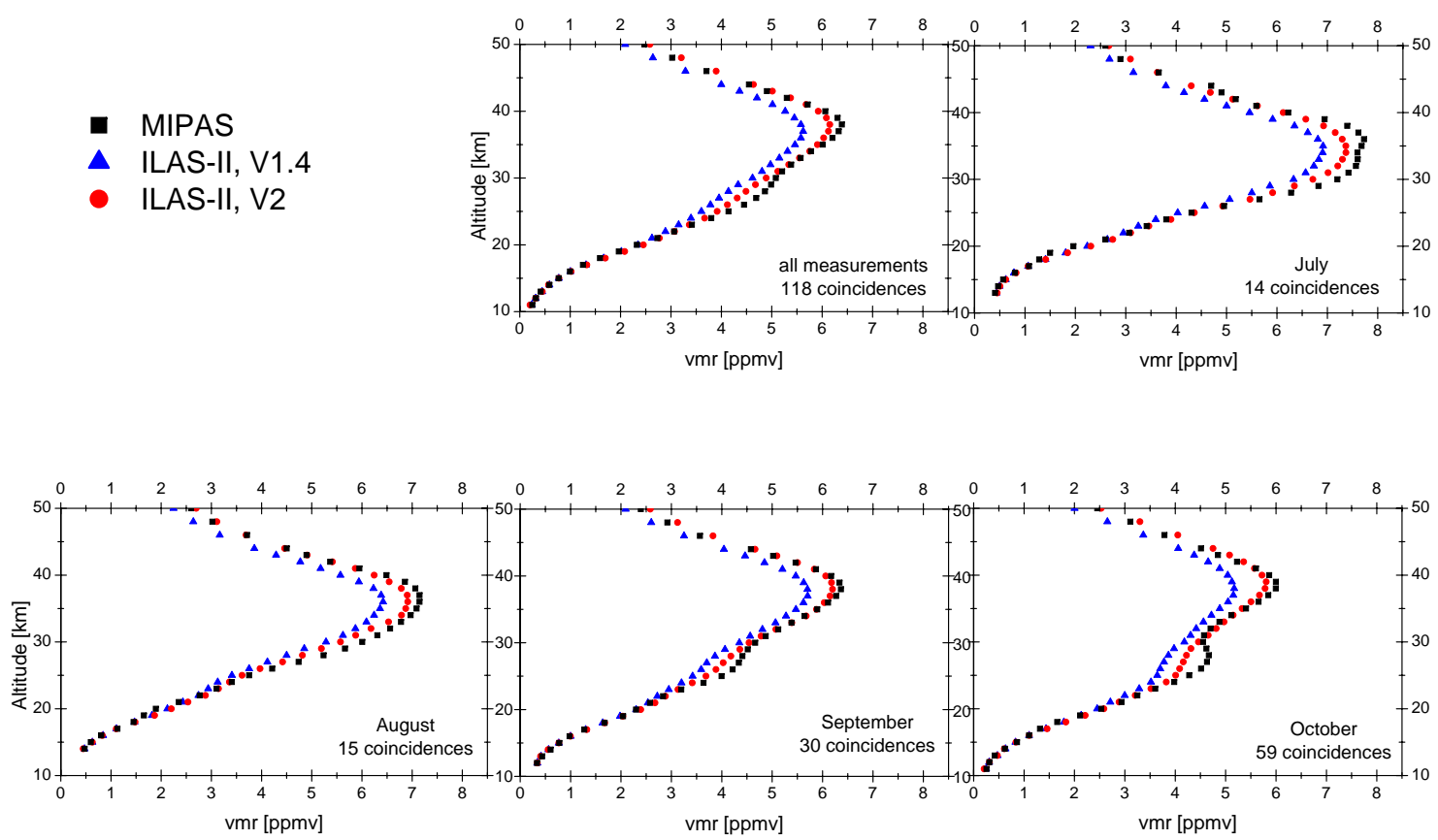

Fig. 4. As in Fig. 1 but for $\mathrm{O}_{3}$. 

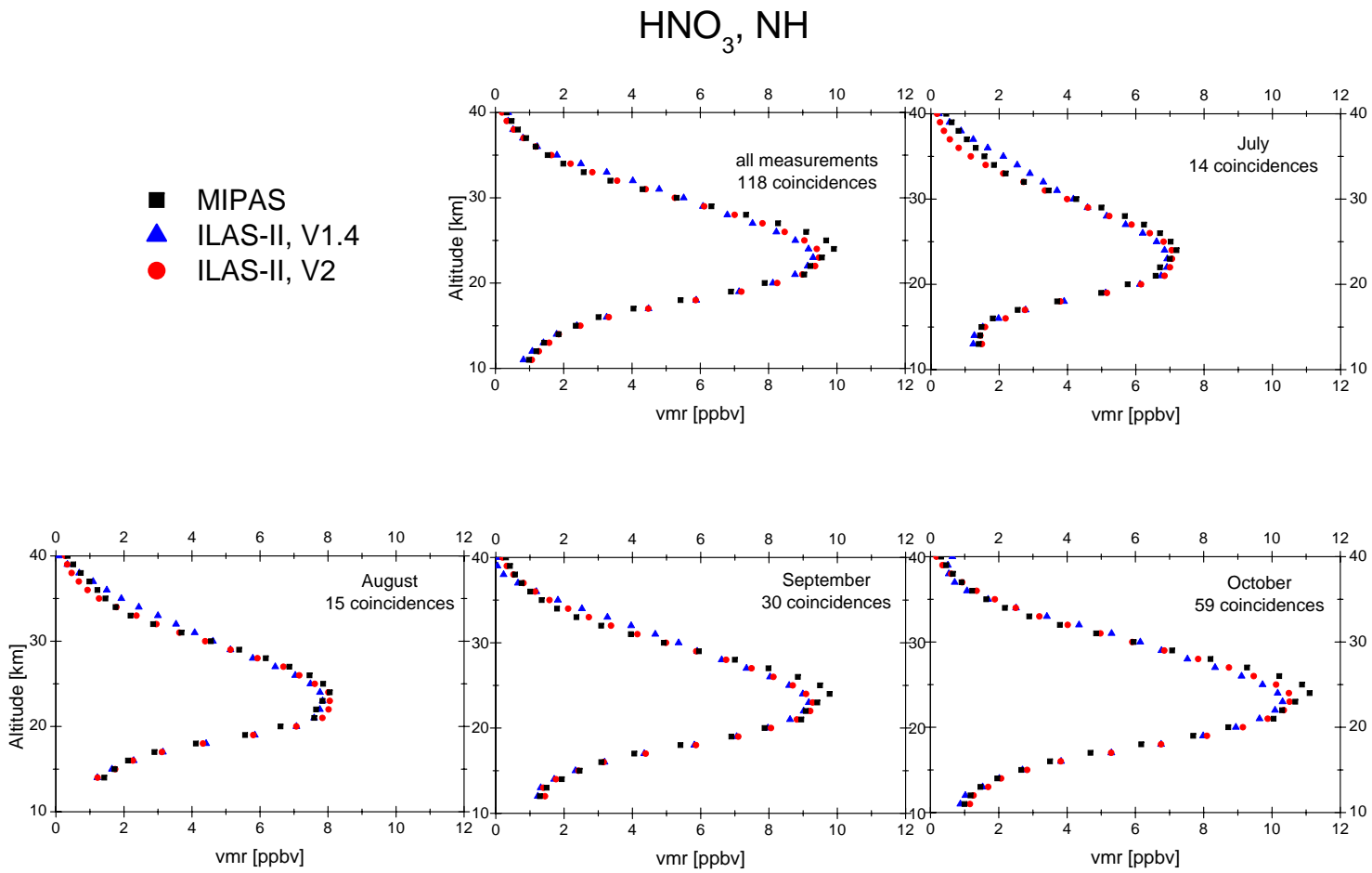

Fig. 5. As in Fig. 1 but for $\mathrm{HNO}_{3}$.

$\mathrm{ClONO}_{2}, \mathrm{NH}$

- MIPAS

- ILAS-II, V1.4

- ILAS-II, V2
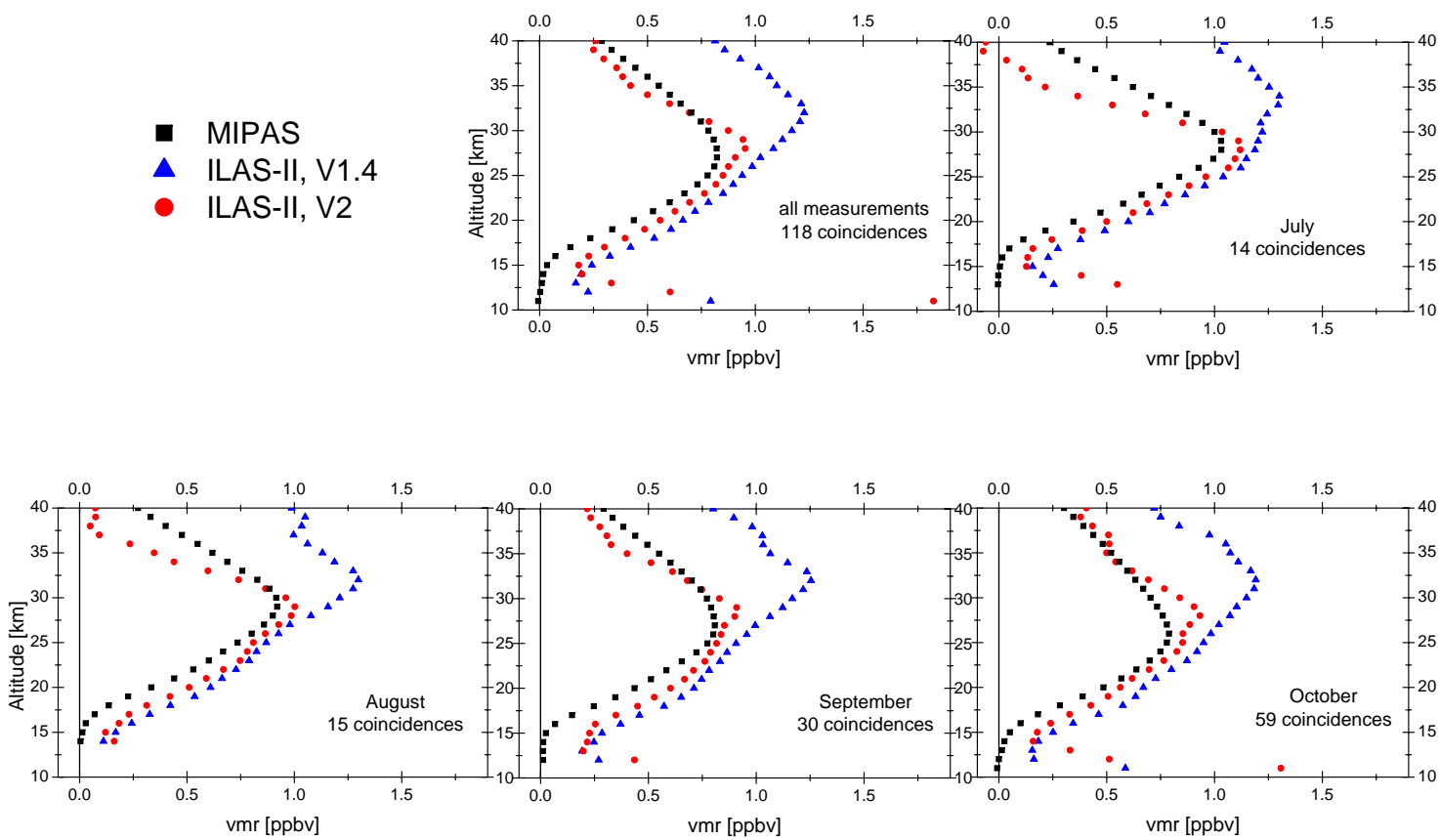

Fig. 6. As in Fig. 1 but for $\mathrm{ClONO}_{2}$. 

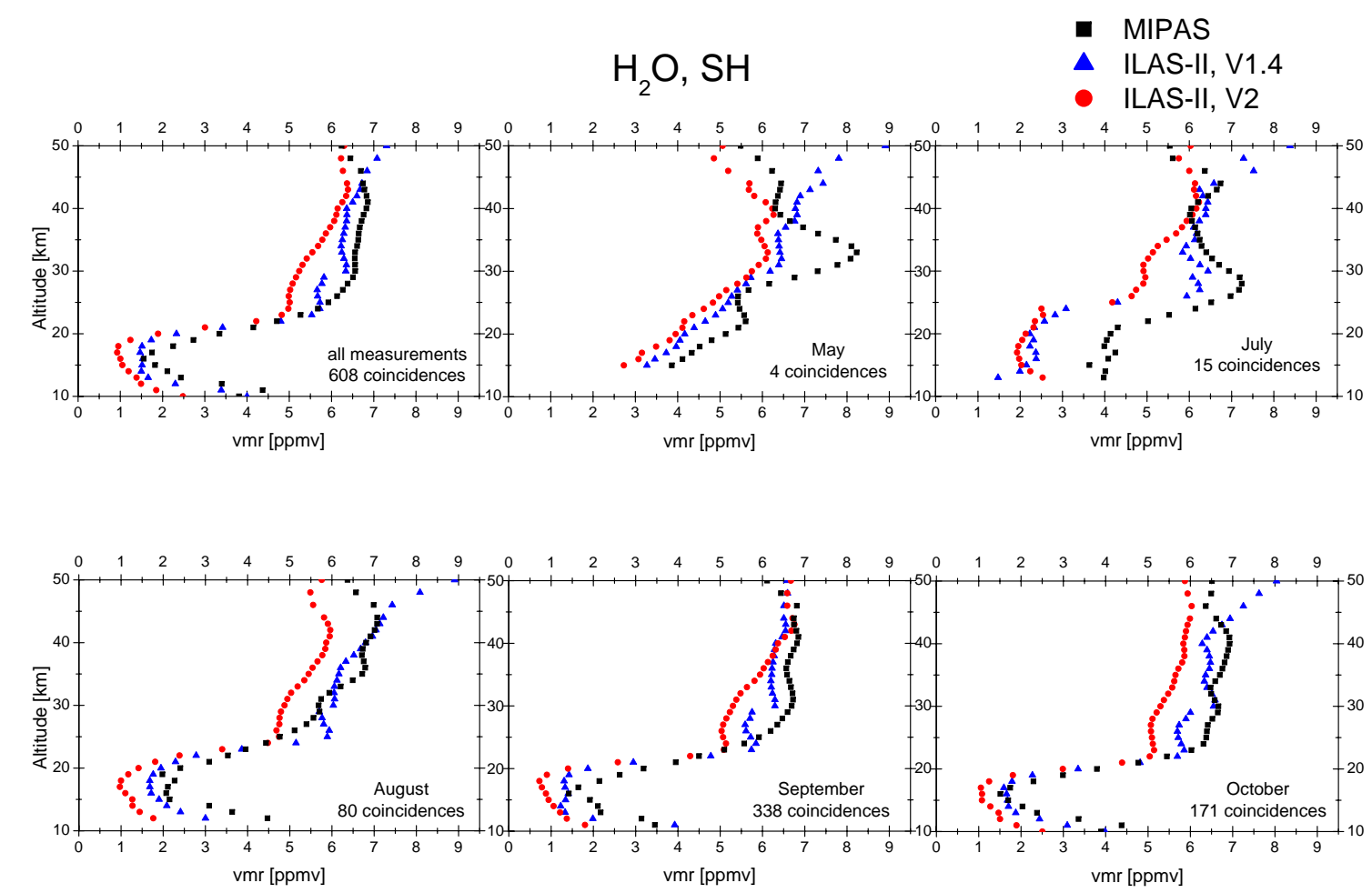

Fig. 7. Comparison of the $\mathrm{H}_{2} \mathrm{O}$ measurements in the $\mathrm{SH}$. The mean profiles of the MIPAS measurements are shown as black squares, the mean profiles of the ILAS-II V1.4 data as blue triangles, and the mean profiles of the ILAS-II V2 data as red circles for each month in which we found coincidences.
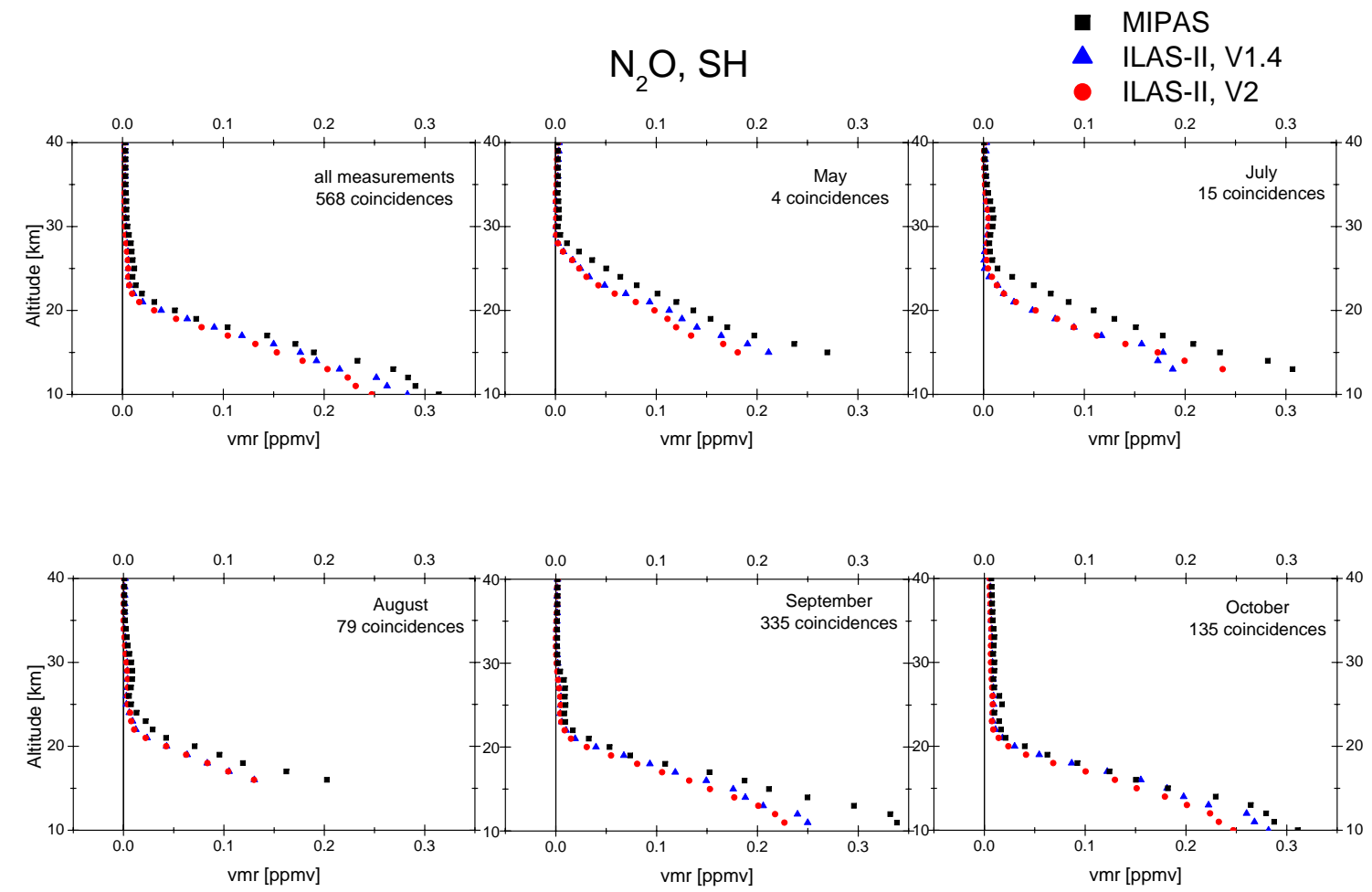

Fig. 8. As in Fig. 7 but for $\mathrm{N}_{2} \mathrm{O}$. 
$\mathrm{CH}_{4}, \mathrm{SH}$

MIPAS

$\triangle \quad$ ILAS-II, V1.4

- ILAS-II, V2
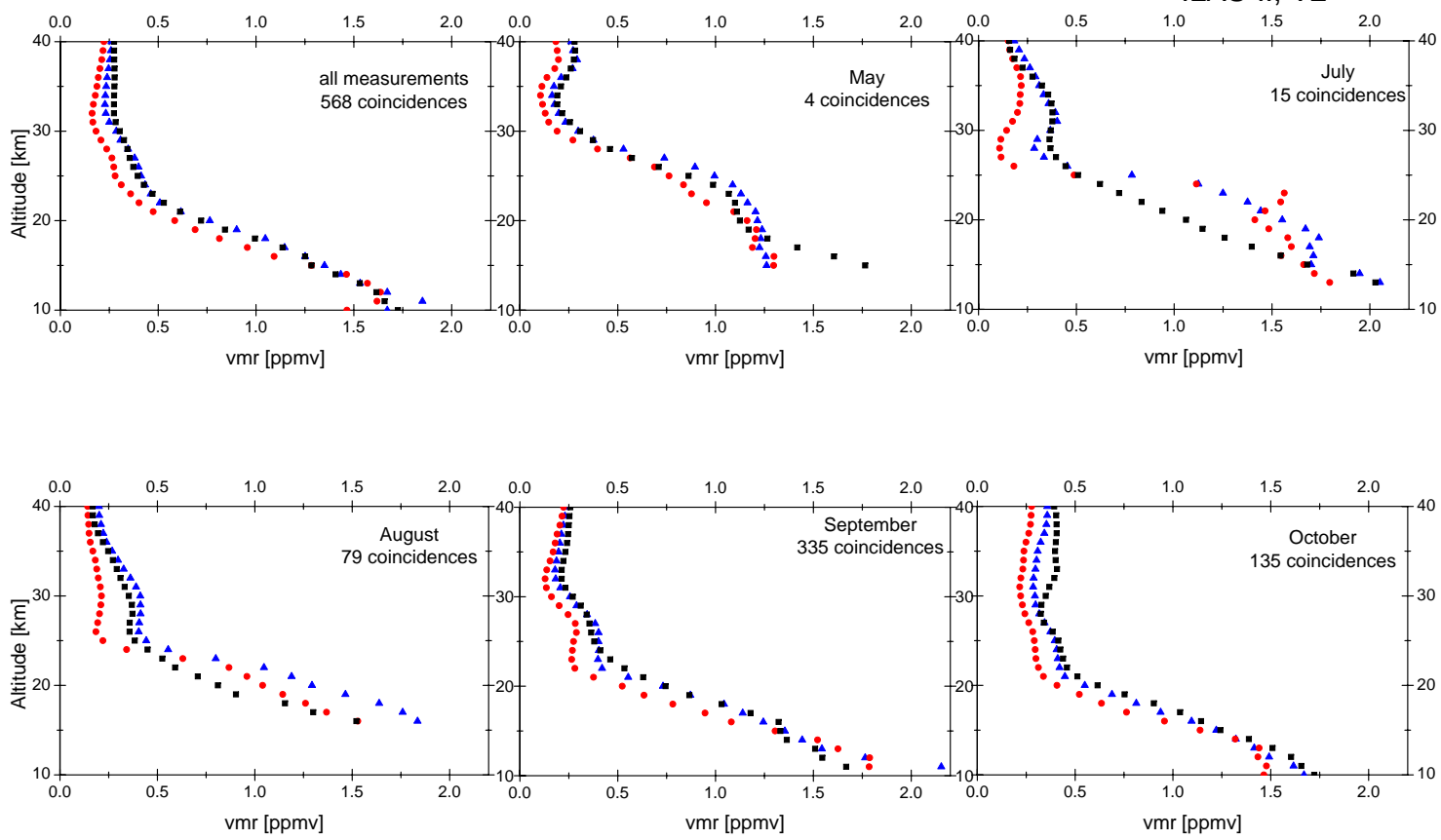

Fig. 9. As in Fig. 7 but for $\mathrm{CH}_{4}$.
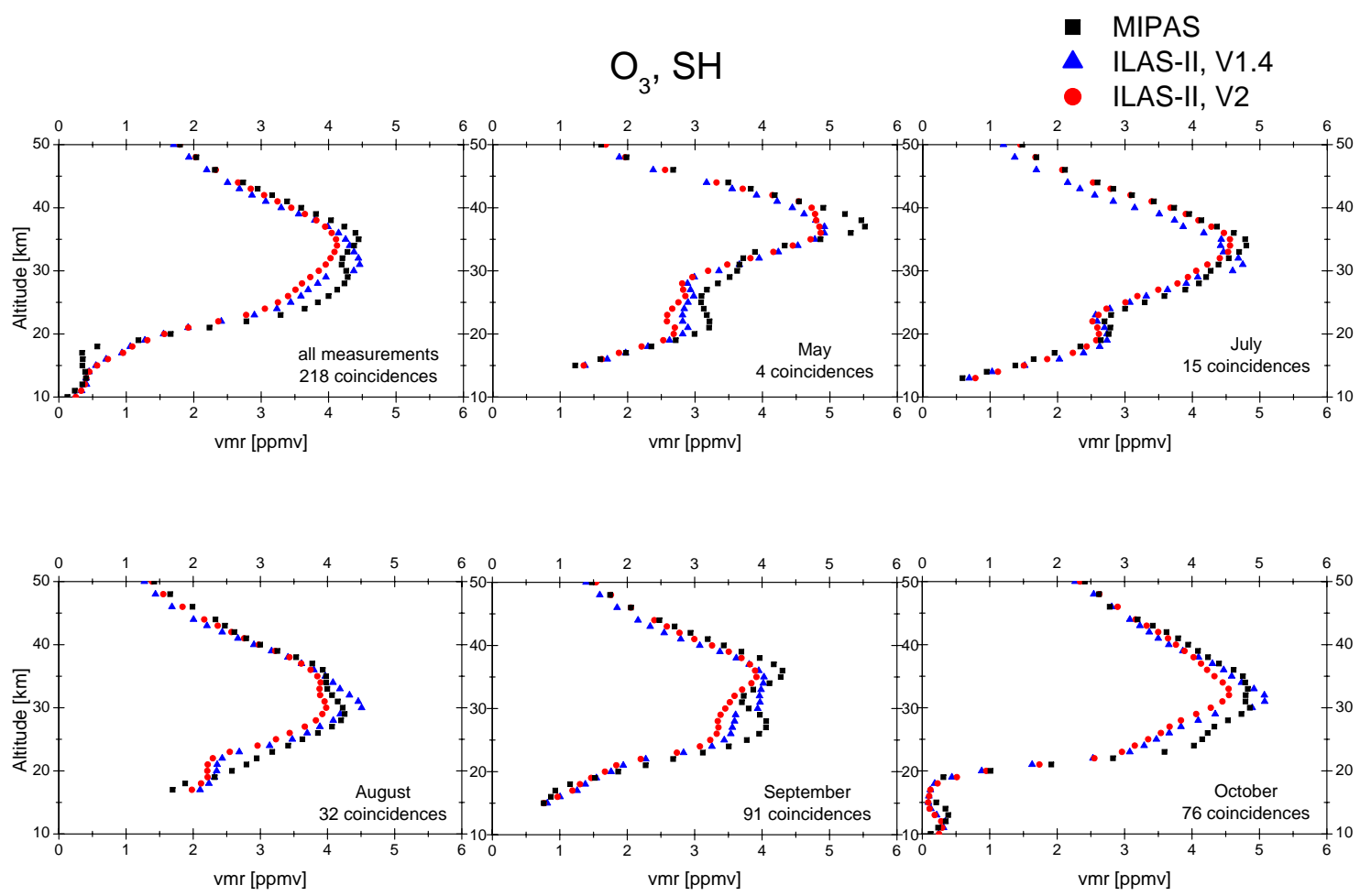

Fig. 10. As in Fig. 7 but for $\mathrm{O}_{3}$. 

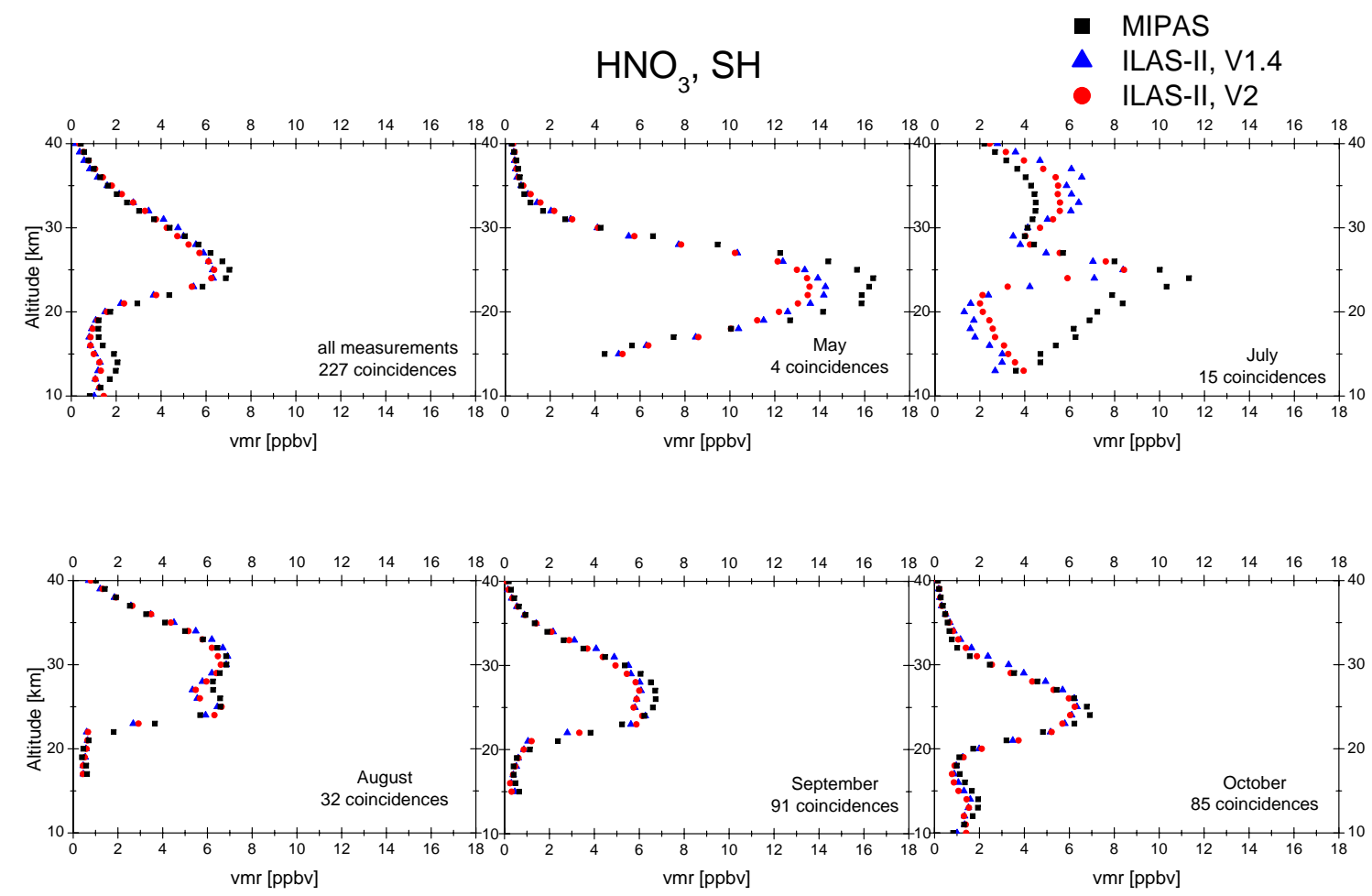

Fig. 11. As in Fig. 7 but for $\mathrm{HNO}_{3}$.
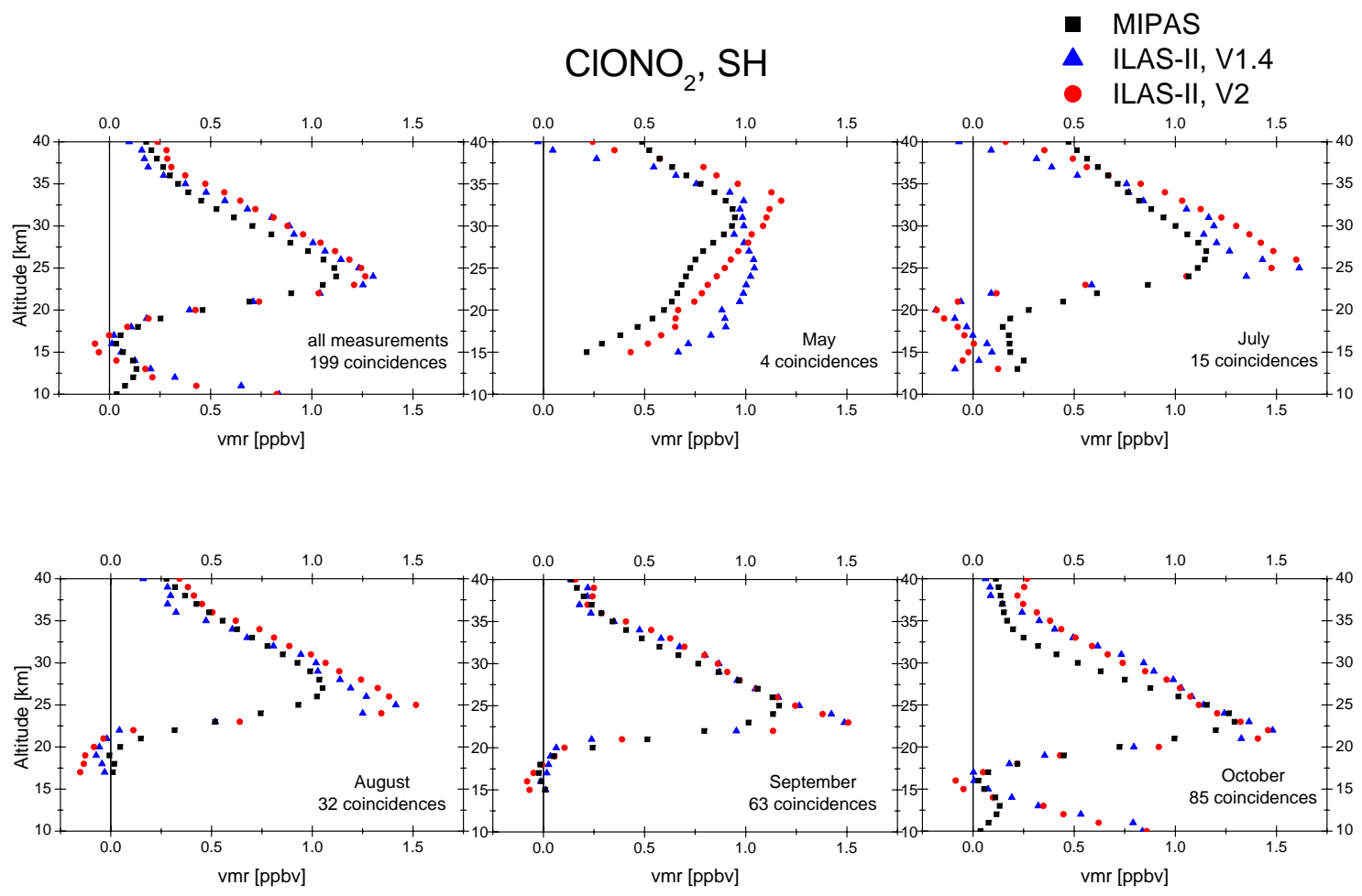

Fig. 12. As in Fig. 7 but for $\mathrm{ClONO}_{2}$. 


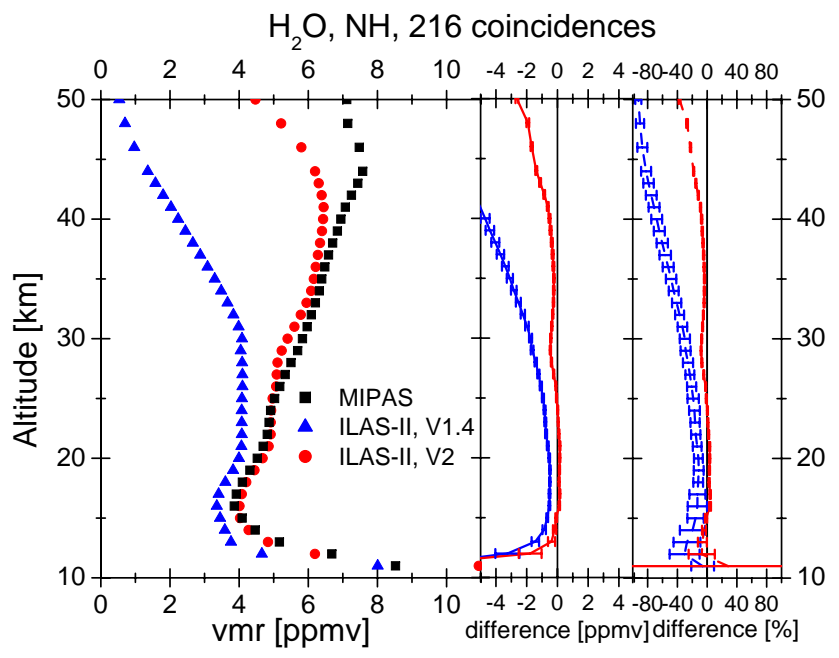

Fig. 13. Differences between ILAS-II and MIPAS measurements of $\mathrm{H}_{2} \mathrm{O}$ in the NH. The mean profiles of all coincidences of the MIPAS measurements are shown as black squares, the mean profiles of the ILAS-II V1.4 data as blue triangles, and the mean profiles of the ILAS-II V2 data as red circles. At the right-hand side the differences in VMR and \% along with the standard error of the mean difference between ILAS-II V1.4 and MIPAS data are shown in blue, and between ILAS-II V2 and MIPAS data in red.

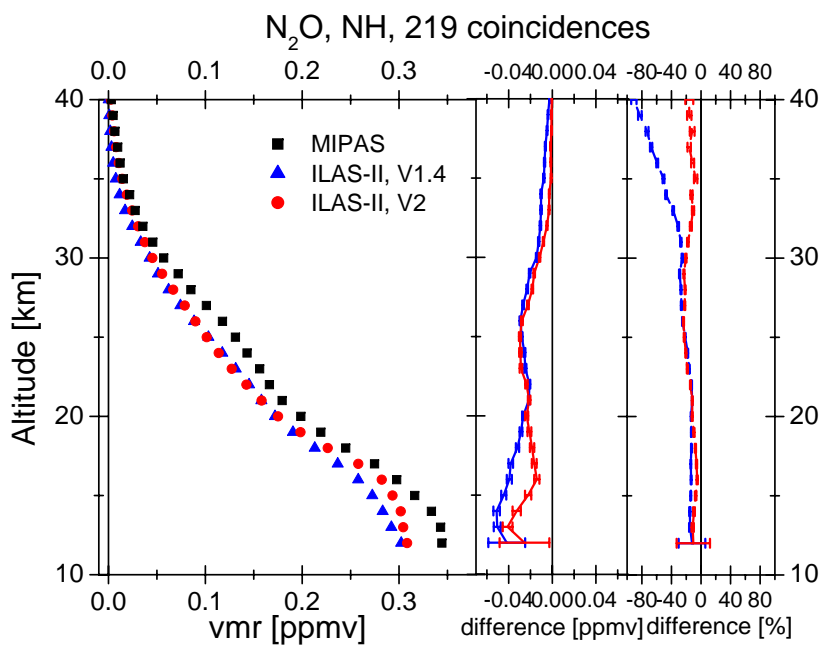

Fig. 14. As in Fig. 13 but for $\mathrm{N}_{2} \mathrm{O}$.

of output signals caused by a deformation of entrance slits of the instrument (Nakajima et al., 2006a). Such results were reported by Ejiri et al. (2006) and Wetzel et al. (2006), in which the data were compared to the Halogen Occultation Experiment (HALOE) measurements or some balloon measurements (MIPAS-B2 and MkIV). Similarly, a negative bias for $\mathrm{O}_{3}$ (Fig. 16) was also found around $40 \mathrm{~km}$. Such a result was reported by Sugita et al. (2006), in which the data

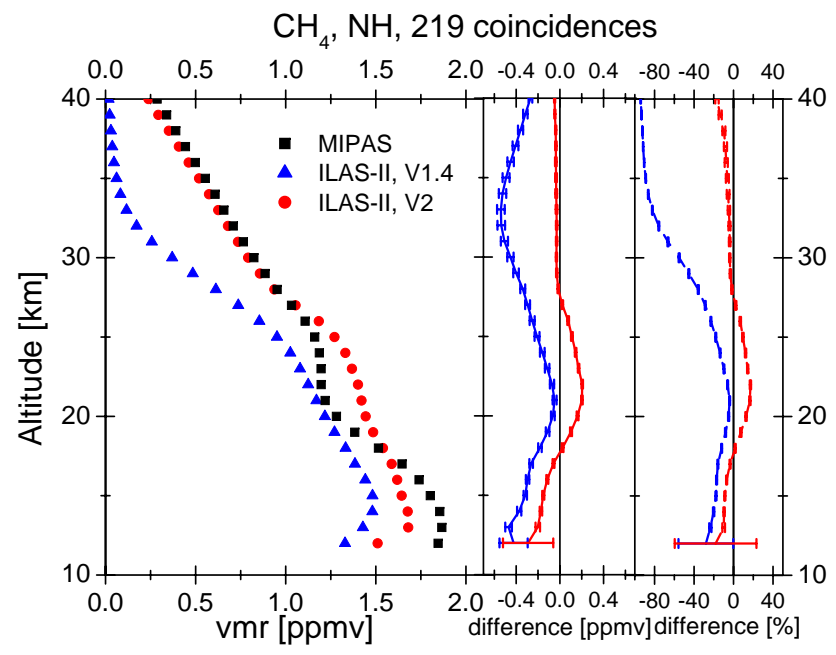

Fig. 15. As in Fig. 13 but for $\mathrm{CH}_{4}$.

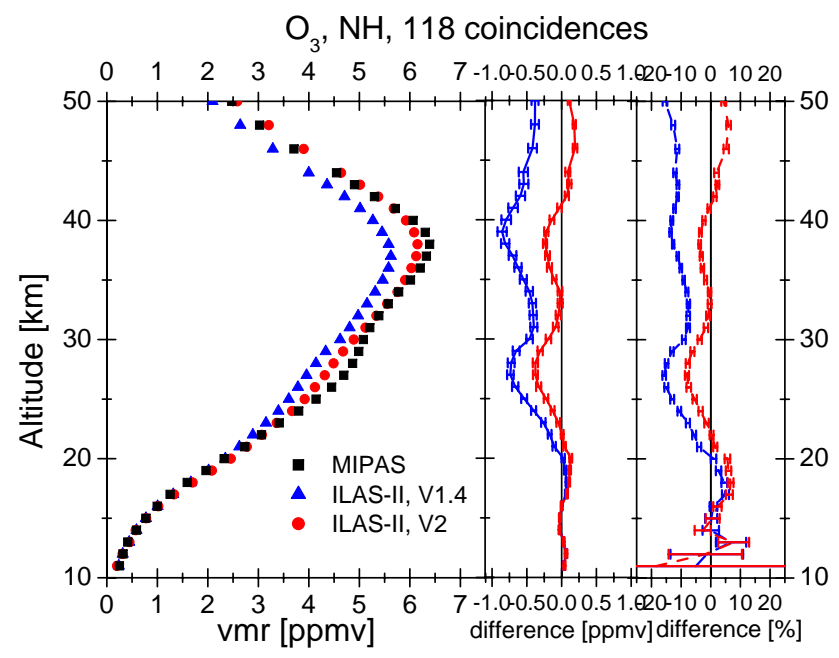

Fig. 16. As in Fig. 13 but for $\mathrm{O}_{3}$.

around $40 \mathrm{~km}$ revealed a negative bias of $\approx 0.6 \mathrm{ppmv}$ compared to some satellite occultation measurements. An inclusion of transmittance correction method developed for the satellite sunrise measurement mode into the ILAS-II V2 retrieval algorithm successfully improved the ILAS-II V2 data of those species.

For $\mathrm{H}_{2} \mathrm{O}$, up to $42 \mathrm{~km}$ there was good agreement between ILAS-II V2 and MIPAS data. At altitudes between 14 and $27 \mathrm{~km}$ and near $35 \mathrm{~km}$ the differences are within their standard errors and thus are not significant. At higher altitudes, the values of the ILAS-II $\mathrm{H}_{2} \mathrm{O}$ data were still smaller than the MIPAS data. The largest differences were found at $50 \mathrm{~km}$ with 2.6 ppmv (37\%). Following the discussion by von Clarmann (2006), percentage differences were calculated as the ratio of mean mixing ratios times 100 rather than the mean 


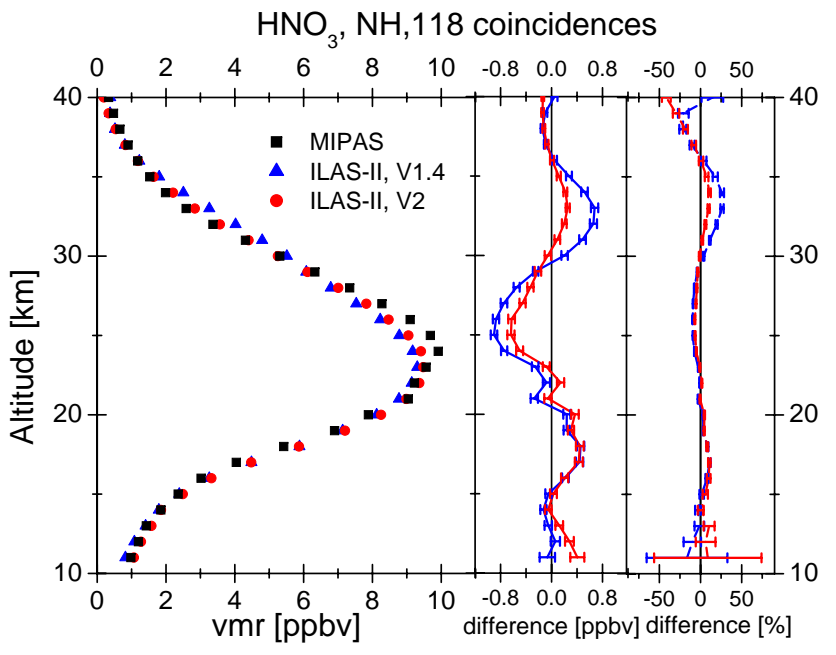

Fig. 17. As in Fig. 13 but for $\mathrm{HNO}_{3}$.

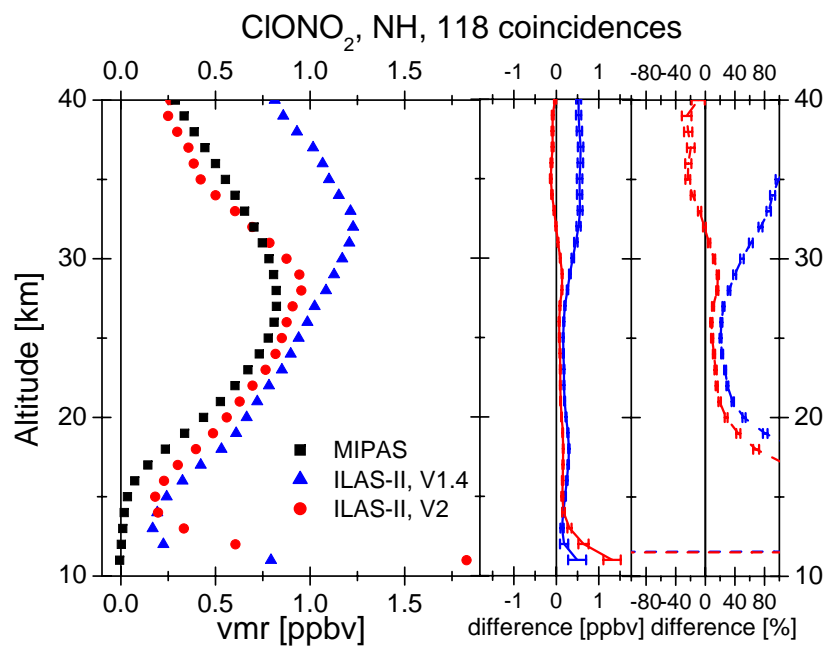

Fig. 18. As in Fig. 13 but for $\mathrm{ClONO}_{2}$.

of individual percentage value. Since the impact of the signal distortion seems to depend on the species and altitude (Ejiri et al., 2006; Nakajima et al., 2006a), the correction applied to this ILAS-II V2 algorithm might not be sufficient for these altitudes. We do not recommend using the $\mathrm{NH}$ $\mathrm{H}_{2} \mathrm{O}$ data around $40 \mathrm{~km}$ and above even for V2. The MIPAS $\mathrm{H}_{2} \mathrm{O}$ profiles have already been compared to other instruments. Comparisons to satellite borne instruments as the HALOE or the Atmospheric Chemistry Experiment - Fourier Transform Spectrometer (ACE-FTS) (Bernath et al., 2005) showed good agreement as well as comparisons with balloon measurements (Milz et al. (2005), Milz, M.: Validation of MIPAS-IMK/IAA water vapour profiles, in preparation). Compared to HALOE, MIPAS had a positive bias of 5-10\%, and compared to ACE-FTS, MIPAS had a negative bias of

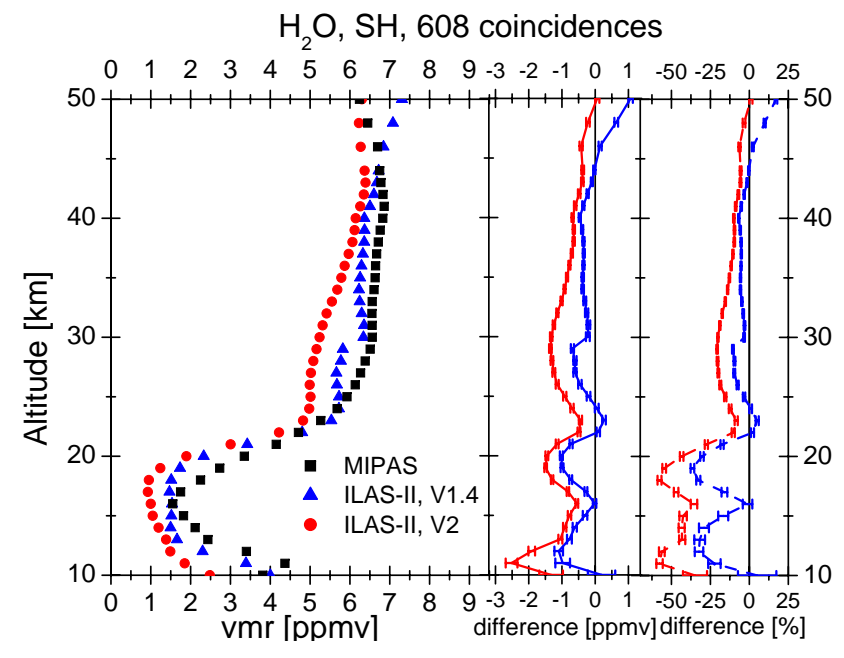

Fig. 19. Differences between ILAS-II and MIPAS measurements of $\mathrm{H}_{2} \mathrm{O}$ in the $\mathrm{SH}$. The mean profiles of all coincidences of the MIPAS measurements are shown as black squares, the mean profiles of the ILAS-II V1.4 data as blue triangles, and the mean profiles of the ILAS-II V2 data as red circles. At the right-hand side the differences in VMR and \% along with the standard error of the mean difference between ILAS-II V1.4 and MIPAS data are shown in blue, and between ILAS-II V2 and MIPAS data in red.

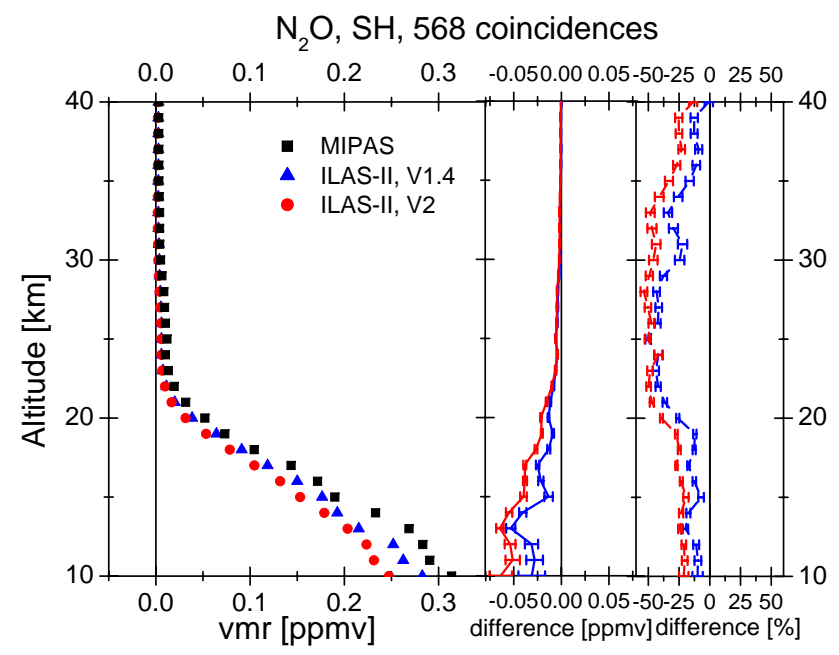

Fig. 20. As in Fig. 19 but for $\mathrm{N}_{2} \mathrm{O}$.

$5 \%$ below $\approx 40 \mathrm{~km}$, which was comparable to the differences found in this study.

For $\mathrm{CH}_{4}$, there was also good agreement between ILAS-II V2 and MIPAS data. The largest differences, with 0.2 ppmv (17\%), were at $22 \mathrm{~km}$. Below $25 \mathrm{~km}$, the biases exceed two times their standard errors and thus are significant. At this altitude range (20-24 km), ILAS-II had difficulty (apparently some high bias) in retrieving $\mathrm{CH}_{4}$ profiles (Ejiri et al., 2006; Kanzawa et al., 2003). Although this is still an open question 


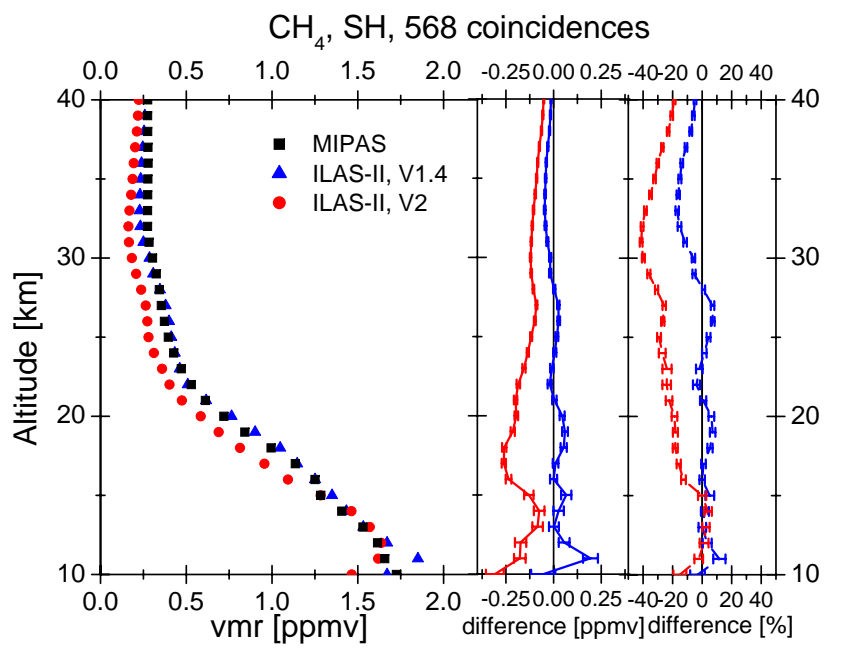

Fig. 21. As in Fig. 19 but for $\mathrm{CH}_{4}$.

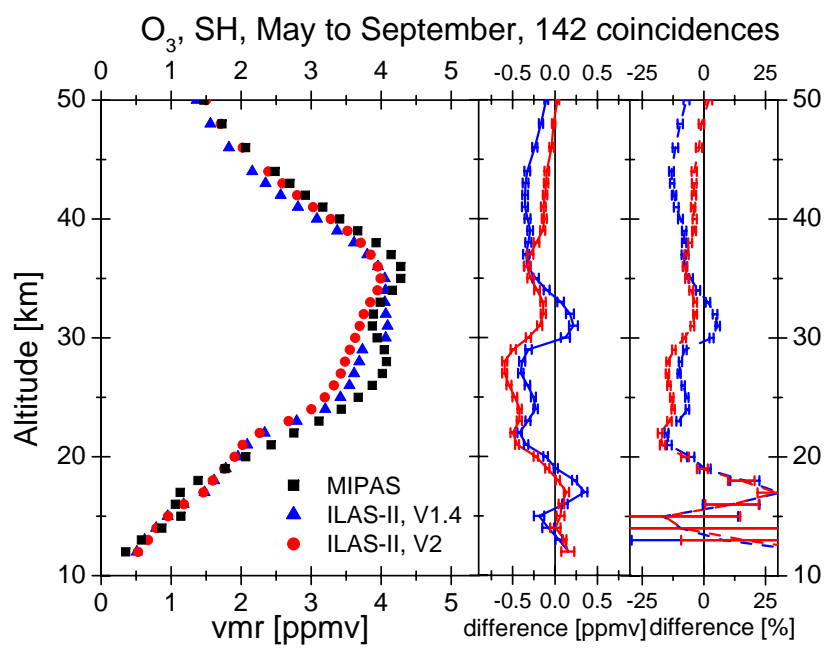

Fig. 22. As in Fig. 19 but for $\mathrm{O}_{3}$ data from May to September.

in the ILAS-II $\mathrm{CH}_{4}$ retrieval, this could contribute to the different vertical structure seen in Fig. 15. In addition, the positive bias of $\mathrm{CH}_{4}$ is also apparent in the correlation between $\mathrm{N}_{2} \mathrm{O}$ and $\mathrm{CH}_{4}$ (see Fig. 26). MIPAS $\mathrm{CH}_{4}$ measurements have not yet been validated. A preliminary comparison with ACEFTS data suggests that MIPAS $\mathrm{CH}_{4}$ mixing ratios may be biased high by approximately $10 \%$ below $40 \mathrm{~km}$ (personal communication, Markus Engelhardt, 2007), which is more recognizable in the $\mathrm{SH}$ comparison.

For $\mathrm{O}_{3}$ comparisons between ILAS-II V2 and MIPAS data, the differences were about $0.3 \mathrm{ppmv}(8-10 \%)$ for nearly the whole height range. Although the mean differences between ILAS-II V2 and MIPAS ozone results are small in absolute terms, they are significant above $23 \mathrm{~km}$. MIPAS $\mathrm{O}_{3}$ has already been validated by Steck et al. (2007), who found

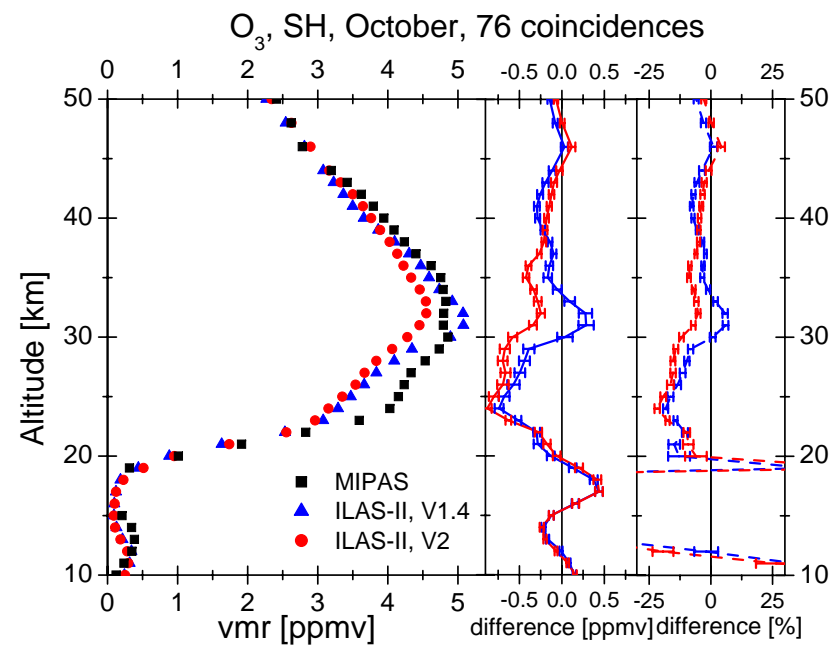

Fig. 23. As in Fig. 19 but for $\mathrm{O}_{3}$ data in October.

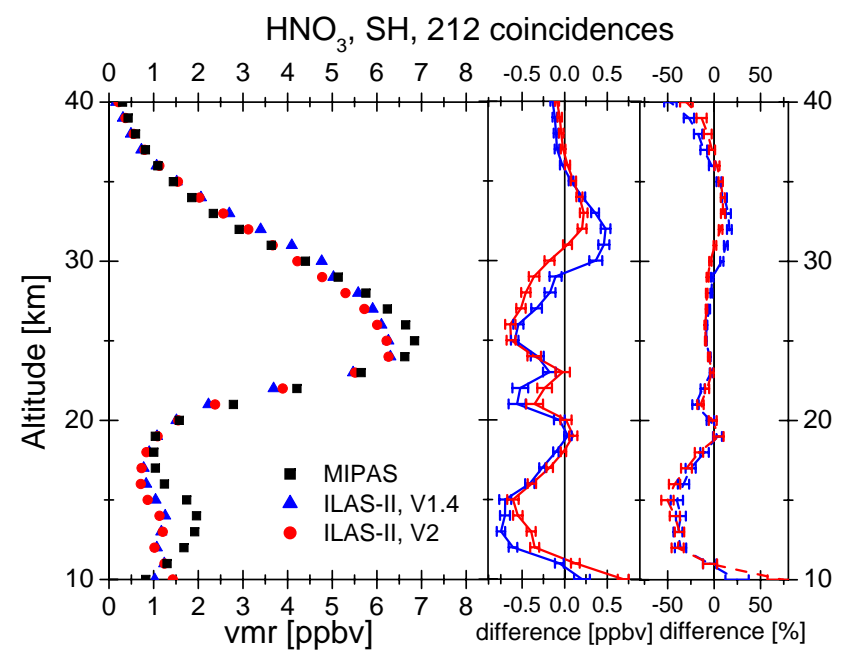

Fig. 24. As in Fig. 19 but for $\mathrm{HNO}_{3}$ data for May and August to October.

mean differences of about $\pm 0.5 \mathrm{ppmv}( \pm 10 \%)$ above $18 \mathrm{~km}$ altitude which is in agreement with the estimated MIPAS systematic error. Below $18 \mathrm{~km}$, mean differences were between -0.1 ppmv and 0.2 ppmv ( $-20 \%$ and $30 \%)$. These differences were again comparable to the differences found in this study.

For $\mathrm{N}_{2} \mathrm{O}$ and $\mathrm{HNO}_{3}$, there were no large differences between the two retrieval versions of ILAS-II. There was good agreement between the ILAS-II and MIPAS data, although the differences exceed the standard errors of the mean difference (Figs. 14 and 17). The largest differences of $\mathrm{N}_{2} \mathrm{O}$ occurred around $13 \mathrm{~km}$ and $14 \mathrm{~km}$ with values of $0.04 \mathrm{ppmv}$ $(10 \%)$ and 0.05 ppmv (15\%) for ILAS-II V2 and V1.4, respectively. Mixing ratios measured by MIPAS were found 


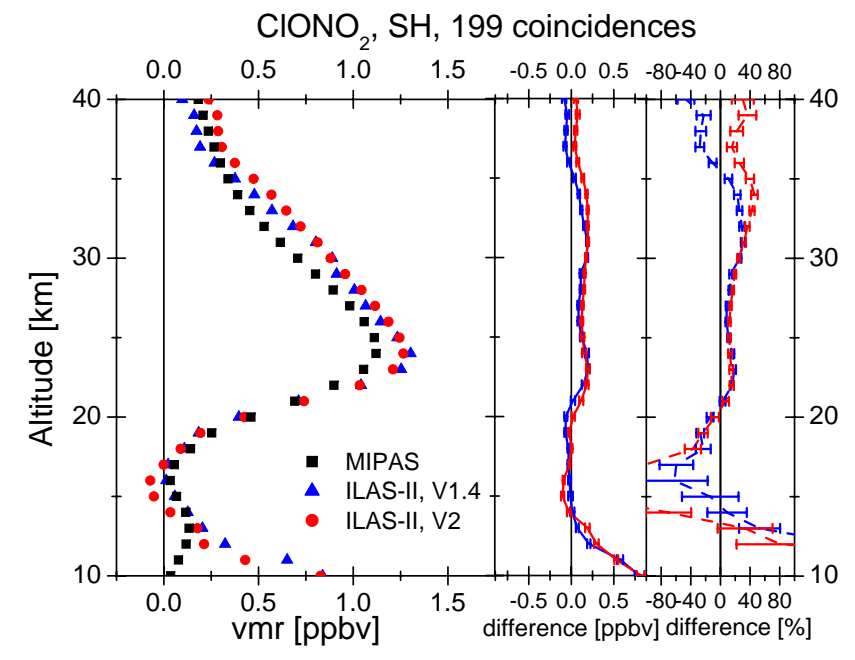

Fig. 25. As in Fig. 19 but for $\mathrm{ClONO}_{2}$.

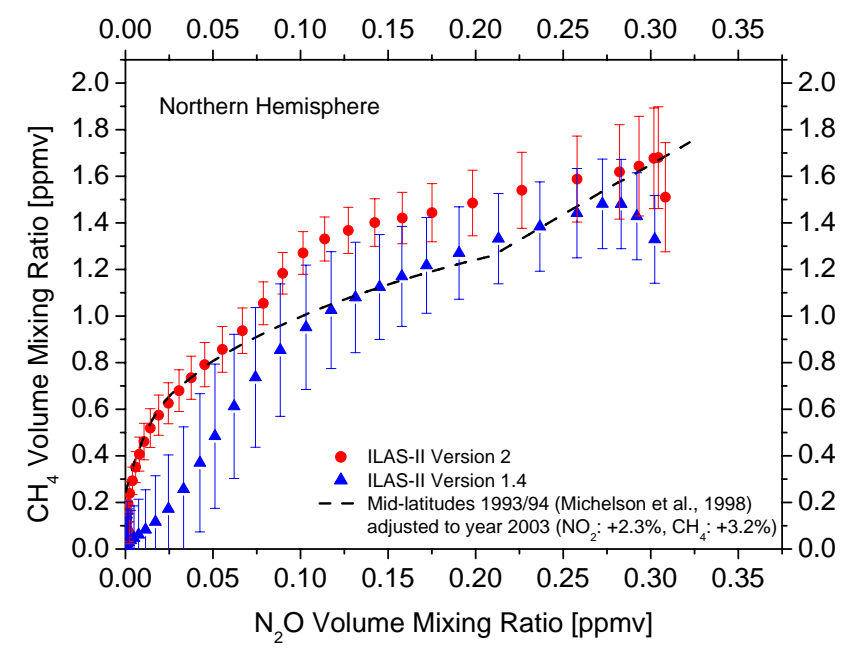

Fig. 26. $\mathrm{N}_{2} \mathrm{O}-\mathrm{CH}_{4}$ relationships as measured by ILAS-II for the $\mathrm{NH}$. The mean values at each $1 \mathrm{~km}$ are used. $1 \sigma$ standard deviations of the data are only shown for $\mathrm{CH}_{4}$ for clarity. Trend-corrected reference correlations observed by other instruments (Michelsen et al., 1998) are shown for comparison.

to be larger than the ILAS-II measurements for the whole height range. Within the ACE-FTS, validation effort comparisons between MIPAS and ACE-FTS $\mathrm{N}_{2} \mathrm{O}$ profiles have been made (Strong et al., 2008). In altitudes higher than 20$25 \mathrm{~km}$, these authors found a similarly good agreement as we found between ILAS-II and MIPAS data. Below these altitudes, MIPAS $\mathrm{N}_{2} \mathrm{O}$ profiles were found to be about $10-15 \%$ larger than those of ACE-FTS. This is consistent with the larger ILAS-II/MIPAS $\mathrm{N}_{2} \mathrm{O}$ differences seen in Fig. 14. This is attributed to a high bias of MIPAS $\mathrm{N}_{2} \mathrm{O}$ at lower altitudes which is, however, unexplained until now.

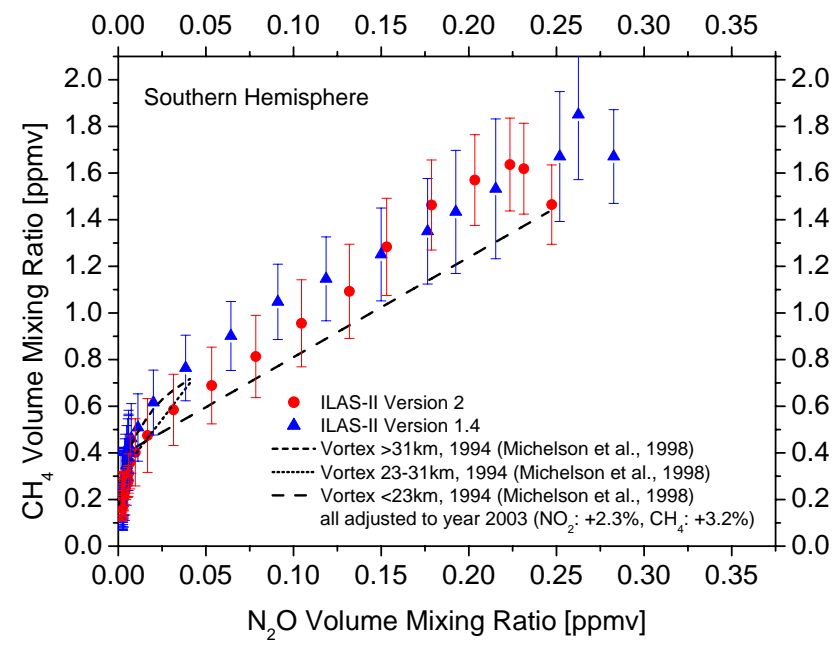

Fig. 27. As in Fig. 26 but for SH.

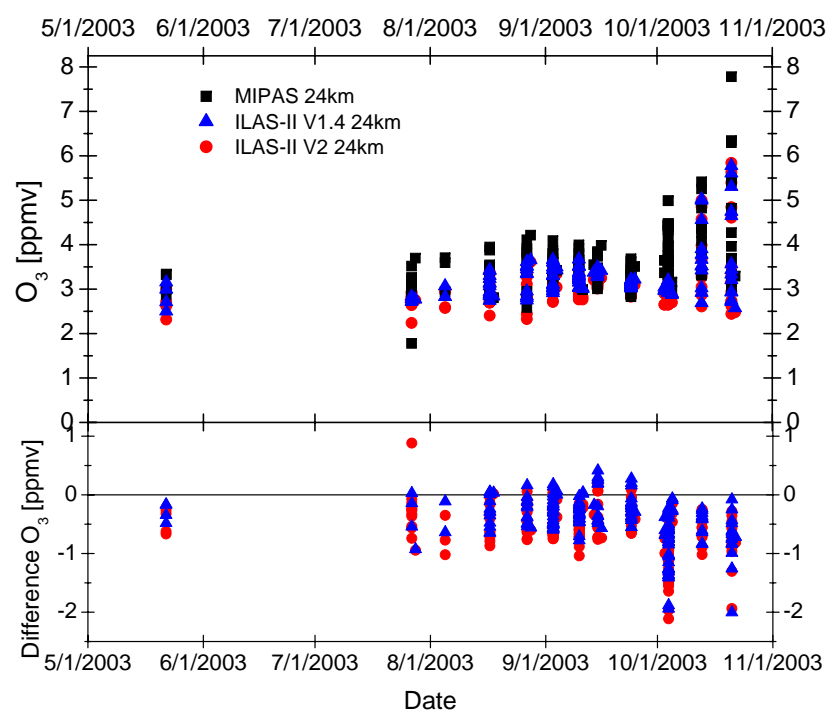

Fig. 28. The time-series of $\mathrm{O}_{3}$ at $24 \mathrm{~km}$ as measured by ILAS-II and MIPAS for the SH.

For $\mathrm{HNO}_{3}$, the largest differences were around $25 \mathrm{~km}$ with $0.6 \mathrm{ppbv}(6.5 \%)$ and $0.9 \mathrm{ppbv}(9 \%)$ for V2 and V1.4, respectively (Fig. 17). These differences were comparable to the differences found by Wang et al. (2007) for the ILAS-II V1.4 data with mean differences being less than $\pm 0.7 \mathrm{ppbv}$ and the standard deviations less than \pm 1 ppbv. It is remarkable that, although the HITRAN 2004 line parameters were used in ILAS-II V2 instead of HITRAN 2000, which was used for ILAS-II V1.4, no large differences were found. These might result from the fact that ILAS-II used not only the $11.3 \mu \mathrm{m}$ band but also the $7.6 \mu \mathrm{m}$ region for the retrieval, which compensates for the high bias of the $11.3 \mu \mathrm{m}$ region (Wang et al., 2007). 
Finally, for $\mathrm{ClONO}_{2}$, although a positive bias was found in the ILAS-II V1.4 data, a significant improvement in the ILAS-II V2 data was seen (Fig. 18), which might also be due to the inclusion of the transmittance correction. For the ILAS-II V2 data, the differences with the MIPAS data (besides at the lowest tangent altitude) were relatively small. The small differences below $30 \mathrm{~km}$ were comparable to the differences found by Höpfner et al. (2007). A diurnal variation of $\mathrm{ClONO}_{2}$ due to photochemistry above $30 \mathrm{~km}$ should be discussed, as was shown in the context of MIPAS intercomparison with the ACE-FTS occultation instrument by application of a chemical transport model (CTM) by Höpfner et al. (2007). However, in that study, application of the CTM led to an overcorrection of the diurnal effect, such that a definite conclusion about the agreement between the two instruments in that altitude range remained open since it is not clear whether the remaining difference is due to CTM-model errors or the instruments. Thus, we have decided not to use such a correction method for the present study.

\subsection{Southern Hemisphere}

The ILAS-II V1.4 SH data did not reveal any degraded profiles as was found for the NH data (Ejiri et al., 2006; Sugita et al., 2006). Since the transmittance correction was not applied to the satellite sunset mode, the differences in VMR between the two algorithm versions were due to the new tangent height registration and the trend correction method for the $100 \%$ signal part data (see Appendix A). The former changed the tangent height ranging from $-110 \mathrm{~m}$ to $-160 \mathrm{~m}$. In such cases, as a lower altitude is assigned for the same measurement spectrum, the resultant VMR generally becomes smaller than that of ILAS-II V1.4. However, as described in Tanaka et al. (2007), the impact of such height changes on retrieved VMR were less than several percentages. Therefore, the relatively large differences between the two versions found for $\mathrm{H}_{2} \mathrm{O}$ and $\mathrm{CH}_{4}$ seem to be due to the latter.

For $\mathrm{H}_{2} \mathrm{O}$, it can be seen that some negative biases exceed their standard errors in the ILAS-II V2 data (Fig. 19). It should be noted that this analysis included a lot of PSC scenes. Therefore, some negative biases could be possible owing to the non-gaseous contribution correction applied to both the ILAS-II V1.4 and V2 algorithms (Oshchepkov et al., 2006), since the changes in VMR with regard to the non-gaseous correction is the most sensitive for $\mathrm{H}_{2} \mathrm{O}$. Using the simultaneous gas-aerosol retrieval scheme (Oshchepkov et al., 2006; Yokota et al., 2002), a preliminary result suggested that the ILAS-II V2 data are, on average, 1-2 ppmv larger than the products applied by this scheme for PSC scenes (S. Oshchepkov, personal communication, 2007). We still need to develop an algorithm that will include this scheme as well as a possible improvement of the trend correction. Then, re-comparisons of the new version data with more validation sources should be made to draw a robust conclusion.

For $\mathrm{N}_{2} \mathrm{O}$ below $22 \mathrm{~km}$, the mean differences exceed twice their standard errors and thus are considered significant (Fig. 20). The largest differences were around $13 \mathrm{~km}$ with 0.06 ppmv (24\%) for V2 and 0.05 ppmv (20\%) for V1.4. Again at lower altitudes the high bias in the MIPAS $\mathrm{N}_{2} \mathrm{O}$ data (Strong et al., 2008) can be seen, similar to the NH.

For $\mathrm{CH}_{4}$, the largest differences for ILAS-II V2 were around $17-18 \mathrm{~km}$ with $0.26 \mathrm{ppmv}(18 \%)$ and for V1.4 around $11 \mathrm{~km}$ with 0.19 ppmv (11\%) (Fig. 21). In the ILAS-II V1.4 validation study, Ejiri et al. (2006) reported that the V1.4 data are somewhat (0.1-0.2 ppmv) larger than HALOE. Thus, V2 had a better agreement with HALOE. It is, therefore, difficult to conclude which version is better based only on these comparison results (i.e., more validation sources are needed). Further, MIPAS $\mathrm{CH}_{4}$ mixing ratios may be biased high by $\approx 10 \%$ below $40 \mathrm{~km}$, as mentioned earlier (M. Engelhardt, personal communication, 2007). The correlation between $\mathrm{N}_{2} \mathrm{O}$ and $\mathrm{CH}_{4}$ in the $\mathrm{SH}$ is also shown in Fig. 27 for reference.

For $\mathrm{O}_{3}$, we have compared the data for different conditions (time periods) in Figs. 22 and 23. A larger negative difference between ILAS-II and MIPAS data was evident in October than in May-September between 20 and $30 \mathrm{~km}$. In October, the largest differences were $0.87 \mathrm{ppmv}(22 \%)$ at $24 \mathrm{~km}$ (Fig. 23). The time-series of $\mathrm{O}_{3}$ values at $24 \mathrm{~km}$ (Fig. 28) also reveals such a feature for both the ILAS-II versions.

The largest differences for $\mathrm{HNO}_{3}$ occurred for the ILAS-II V2 data at $26 \mathrm{~km}$ with $0.64 \mathrm{ppbv}(9.6 \%)$ and, for $\mathrm{ClONO}_{2}$, differences occurred at $31 \mathrm{~km}$ with $0.19 \mathrm{ppbv}$ (32\%) (Figs. 24 and 25). Similar to the NH, differences found in the validation studies of MIPAS data (Steck et al., 2007; Wang et al., 2007; Höpfner et al., 2007) were comparable to the differences found in the present study.

\section{Conclusions}

Two algorithm versions of ILAS-II data were investigated and compared to MIPAS IMK/IAA data. In this study we have shown that for most cases the ILAS-II V2 data fit better with the other validated data than the V1.4 data. The mean differences between ILAS-II V2 and MIPAS data for both hemispheres were within \pm 10 to $37 \%$, depending on the gas. They were of the same order of magnitude as in other MIPAS validation or comparison studies. For both $\mathrm{H}_{2} \mathrm{O}$ and $\mathrm{CH}_{4}$, a clear improvement from the ILAS-II V1.4 to V2 data was noticed in the NH. There were exceptionally small values in these $\mathrm{V} 1.4$ data above $30 \mathrm{~km}$. $\mathrm{NH} \mathrm{O}_{3}$ also showed an improvement above $40 \mathrm{~km}$ in the $\mathrm{V} 2$ data. In $\mathrm{NH} \mathrm{ClONO}_{2}$ data, an improvement from the V1.4 data with exceptional large values to the $\mathrm{V} 2$ data was also obvious. For $\mathrm{SH} \mathrm{H}_{2} \mathrm{O}$, the agreements were better between ILAS-II V1.4 and MIPAS data than with ILAS-II V2 data. In this case, we need a 
more refined retrieval (Oshchepkov et al., 2006) with a more comprehensive comparison study to decide which version is better, but such particular analysis is beyond the scope of this study. The ILAS-II V1.4 data set $\left(\mathrm{O}_{3}, \mathrm{HNO}_{3}, \mathrm{~N}_{2} \mathrm{O}\right.$, and $\mathrm{CH}_{4}$ for gases) is publicly available through the ILAS-II web site (http://www-ilas2.nies.go.jp). The ILAS-II V2 data set (all gases described in this study) will also be available through it. The authors clearly recommend the use of ILAS-II V2 for further studies, as V1.4 data have some problems, especially in the $\mathrm{NH}$ (exceptionally small or large values due to signal distortion). For $\mathrm{SH}_{2} \mathrm{O}$ data, further data quality evaluation is necessary.

\section{Appendix A}

\section{Processing differences between ILAS-II V1.4 and V2}

In this $\mathrm{V} 2$ retrieval algorithm, there are several upgrades from V1.4 data (Nakajima et al., 2006a). Here, we only describe points that relate to the retrieval for gases. A further description is found at an ILAS-II web site (http: //www-ilas2.nies.go.jp).

\section{A1 Transmittance correction}

This method was applied to correct abnormal transmittance caused by the distortion in the entrance slit due to solar heat energy in the orbit (Sect. 3.3 of Nakajima et al., 2006a). This correction was applied only for NH data, because the effect of transmittance distortion on retrieved gas profiles apparently appeared only for sunrise occultation events (see also Sects. 2.1 and 4.1). This is because the degrees of plastic deformation at the atmospheric transmission parts were different owing to the different measurement sequences (Yokota et al., unpublished manuscript, available through the ILAS-II web site).

So far, we found that there is a relation between distorted solar disk and slits images obtained by a Sun-Edge Sensor (SES) and output signals obtained by the IR channel. The degree of the distorted solar disk and slits images from the theoretical ones (see Fig. 11 of Nakajima et al., 2006a) was used for estimating the correct transmittance. We have developed a model to correct the output signals from the distortion in the entrance slit by using the following four parameters:

- Degree of vertical movement (in $\mu \mathrm{m}$ ) of a lower edge of the entrance slit for IR, MIR, and VIS channels $(L)$

- Degree of vertical movement (in $\mu \mathrm{m}$ ) of an upper edge of that $(U)$

- Slit alignment offset relative to the secondary (spectrometer) slit positions $(A)$

- Element numbers (range) of SES used for transmittance residual calculation $(R)$
Among these parameters, A was fixed at $-10 \mu \mathrm{m}$ according to the laboratory experiment. A schematic of the slit alignment is shown in Fig. 4 of Nakajima et al. (2006a). The size of the entrance slit is $2.4 \mathrm{~mm}$ in width and $0.2 \mathrm{~mm}$ in height. These three remaining parameters were determined on a daily basis by comparing the modeling of transmittance measured by ILAS-II and the reference transmittance calculated by using gas profiles from other satellite sensors.

First, the theoretical solar disk image was created for SES wavelength $(1050 \mathrm{~nm})$ using the theoretical limb-darkening effect and aerosol extinction coefficient at $780 \mathrm{~nm}$ data for each scene. Also, smeared sun-edge shape, which occurred owing to the effect of instrument function, was considered.

Second, ILAS-II correlative measurements were searched for other satellite sensors data; HALOE and MIPAS. As a result, 177 matching events were picked up from MIPAS (from 7 April to 13 October 2003) and from HALOE (in May, 2003). By using gas mixing ratio profiles from these data products, reference transmittance spectra of the ILAS-II IR channel were calculated. Assuming this reference transmittance as true value, the three parameters $(L, U$, and $R)$ were iteratively solved to minimize the root-sum-square residuals between the corrected transmittance spectra of the IR channel's element numbers between 1 and 8 and those calculated by the reference ones. For the residual calculation, the altitude range between 20 and $40 \mathrm{~km}$ was used.

Third, to apply the determined parameters for whole measurement period of ILAS-II (from January to October 2003), time variations of parameters $L$ and $U$ are linearly interpolated into time. Time variation of parameter $R$ was fit with a third-order polynomial with time.

\section{A2 Tangent height $(\mathrm{TH})$ registration}

The ILAS-II V1.4 data had difficulty in determining the TH, especially below $30 \mathrm{~km}$, due to SES signal distortion and PSC occurrences (Tanaka et al., 2007). In V1.4, about 200 scenes were excluded in the data set because of the PSC occurrence. Further, there was some altitude gap between 30 and $31 \mathrm{~km}$, depending on scenes, since V1.4 used a combined method of two TH registrations (Tanaka et al., 2007). The abnormal SES signal was also caused by the distortion in the entrance slits due to solar heat energy in orbit, as mentioned earlier. For V2, we applied a new method using information of the angle of the gimbal mirror to eliminate the difficulties mentioned earlier. The gimbal mirror is arranged to guide incident sun light to the spectrometers and the angle of the gimbal mirror is recorded during measurements of ILAS-II. By using the position of the satellite, the earth, and the gimbal mirror angle, we calculated the optical path of IFOV center, then the TH was derived. As a result, the assigned THs in V2 were $180 \mathrm{~m}( \pm 140 \mathrm{~m}$ of $1 \sigma$ standard deviation for $N=2845$ ) higher than those in $\mathrm{V} 1.4$ at $\mathrm{TH}=20 \mathrm{~km}$ in $\mathrm{NH}$, and were $150 \mathrm{~m}( \pm 130 \mathrm{~m}$ for $N=2711)$ lower than in $\mathrm{SH}$. 


\section{A3 Trend correction in $100 \%$ level signal part}

Only in the sunset mode measurements, there were less measurement frames above an altitude of $80 \mathrm{~km}$ in the atmospheric measurement part for a lot of scenes. In addition, the $100 \%$ level signal part was partly affected by the plastic deformation of the entrance slits, unlike for the sunrise mode measurements where the atmospheric measurement part was affected, Therefore, a conventional trend correction method for the $100 \%$ level signal part data (Yokota et al., 2002) could not be applied for the sunset events. Instead, a brief method was developed and applied in V2; the output signal at TH of $80 \mathrm{~km}$ was used for the $100 \%$ level.

\section{A4 Other revised items}

The effect of solar limb-darkening in the IR channel was calculated theoretically and was corrected. The same type of correction had already been applied in the version 5.2 algorithm used for the original ILAS instrument (Yokota et al., 2002). The look-up table for calculating absorption crosssection data in the forward calculating procedure was reconstructed by using the HITRAN 2004 database (Rothman et al., 2005) instead of the HITRAN 2000 database (Rothman et al., 2003), which was used for the old algorithm version. The instrument function was refined using laboratory test data which were obtained prior to the satellite launch. Also, the effect of the cross-talk between the detector elements was changed to $5 \%$ (in V1.4, a value of $2.5 \%$ was incorrectly used). The retrieved gas profiles were re-evaluated by considering systematic residuals found in the measured transmittance spectra (Appendix of Nakajima et al., 2006b). Consequently, internal errors were calculated from the final residuals of convergence in the non-linear least squares spectral fitting. These errors were estimated from the second retrieval results after subtracting estimated spectral biases. As a result, retrieved profiles were slightly changed but the internal error values were reduced from the first to the second retrievals, which is comparable to repeatability (Yokota et al., unpublished manuscript, available through the ILAS-II web site) applied in the V1.4 data. Although other minor revisions were made, they can be also found at the ILAS-II web site.

Acknowledgements. The ILAS-II project was funded by the Ministry of the Environment, Japan (MOE). A part of this research was supported by the Global Environment Research Fund (GERF) provided by the MOE. M. Engelhardt and S. Oshchepkov kindly showed us their comparison results prior to publication.

Edited by: M. van Roozendael

\section{References}

Bernath, P. F., McElroy, C. T., Abrams, M. C., Boone, C. D., Butler, M., Camy-Peyret, C., Carleer, M., Clerbaux, C., Coheur, P.-F., Colin, R., DeCola, P., DeMazière, M., Drummond, J. R., Dufour, D., Evans, W. F. J., Fast, H., Fussen, D., Gilbert, K., Jennings, D. E., Llewellyn, E. J., Lowe, R. P., Mahieu, E., McConnell, J. C., McHugh, M., McLeod, S. D., Michaud, R., Midwinter, C., Nassar, R., Nichitiu, F., Nowlan, C., Rinsland, C. P., Rochon, Y. J., Rowlands, N., Semeniuk, K., Simon, P., Skelton, R., Sloan, J. J., Soucy, M.-A., Strong, K., Tremblay, P., Turnbull, D., Walker, K. A., Walkty, I., Wardle, D. A., Wehrle, V., Zander, R., and Zou, J.: Atmospheric Chemistry Experiment (ACE): Mission overview, Geophys. Res. Lett., 32, L15S01, doi: 10.1029/2005GL022386, 2005.

Bracher, A., Bovensmann, H., Bramstedt, K., Burrows, J. P., von Clarmann, T., Eichmann, K.-U., Fischer, H., Funke, B., GilLópez, S., Glatthor, N., Grabowski, U., Höpfner, M., Kaufmann, M., Kellmann, S., Kiefer, M., Koukouli, M. E., Linden, A., López-Puertas, M., Mengistu Tsidu, G., Milz, M., Noël, S., Rohen, G., Rozanov, A., Rozanov, V. V., von Savigny, C., Sinnhuber, M., Skupin, J., Steck, T., Stiller, G. P., Wang, D.-Y., Weber, M., and Wuttke, M. W.: Cross comparisons of $\mathrm{O}_{3}$ and $\mathrm{NO}_{2}$ measured by the atmospheric ENVISAT instruments GOMOS, MIPAS, and SCIAMACHY, Adv. Space Res., 36, 855-867, doi: 10.1016/j.asr.2005.04.005, 2005.

Ejiri, M. K., Terao, Y., Sugita, T., Nakajima, H., Yokota, T., Toon, G. C., Sen, B., Wetzel, G., Oelhaf, H., Urban, J., Murtagh, D., Irie, H., Saitoh, N., Tanaka, T., Kanzawa, H., Shiotani, M., Kobayashi, H., and Sasano, Y.: Validation of the Improved Limb Atmospheric Spectrometer-II ILAS-II Version 1.4 nitrous oxide and methane profiles, J. Geophys. Res., 111, D22S90, doi: 10.1029/2005JD006449, 2006.

Fischer, H., Birk, M., Blom, C., Carli, B., Carlotti, M., von Clarmann, T., Delbouille, L., Dudhia, A., Ehhalt, D., Endemann, M., Flaud, J. M., Gessner, R., Kleinert, A., Koopmann, R., Langen, J., López-Puertas, M., Mosner, P., Nett, H., Oelhaf, H., Perron, G., Remedios, J., Ridolfi, M., Stiller, G., and Zander, R.: MIPAS: an instrument for atmospheric and climate research, Atmos. Chem. Phys. Discuss., 7, 8795-8893, 2007, http://www.atmos-chem-phys-discuss.net/7/8795/2007/.

Flaud, J.-M., Piccolo, C., Carli, B., Perrin, A., Coudert, L. H., Teffo, J.-L., and Brown, L. R.: Molecular line parameters for the MIPAS (Michelson Interferometer for Passive Atmospheric Sounding) experiment, Atmos. Oceanic Opt., 16, 172-182, 2003.

Funke, B., López-Puertas, M., Stiller, G. P., von Clarmann, T., and Höpfner, M.: A new non-LTE Retrieval Method for Atmospheric Parameters From MIPAS-ENVISAT Emission Spectra, Adv. Space Res., 27, 1099-1104, 2001.

Glatthor, N., von Clarmann, T., Fischer, H., Funke, B., Grabowski, U., Höpfner, M., Kellmann, S., Kiefer, M., Linden, A., Milz, M., Steck, T., Stiller, G. P., Mengistu Tsidu, G., and Wang, D. Y.: Mixing processes during the Antarctic vortex split in September/October 2002 as inferred from source gas and ozone distributions from ENVISAT-MIPAS, J. Atmos. Sci., 62, 787-800, 2005.

Höpfner, M., Stiller, G. P., Kuntz, M., von Clarmann, T., Echle, G., Funke, B., Glatthor, N., Hase, F., Kemnitzer, H., and Zorn, S.: The Karlsruhe optimized and precise radiative transfer algorithm. Part II: Interface to retrieval applications, in: Optical Remote 
Sensing of the Atmosphere and Clouds, Beijing, China, 15-17 September 1998, edited by: Wang, J., Wu, B., Ogawa, T., and Guan, Z., Vol. 3501, 186-195, 1998.

Höpfner, M., von Clarmann, T., Fischer, H., Glatthor, N., Grabowski, U., Kellmann, S., Kiefer, M., Linden, A., Mengistu Tsidu, G., Milz, M., Steck, T., Stiller, G. P., Wang, D.-Y., and Funke, B.: First spaceborne observations of Antarctic stratospheric $\mathrm{ClONO}_{2}$ recovery: Austral spring 2002, J. Geophys. Res., 109, D11308, doi:10.1029/2004JD004609, 2004.

Höpfner, M., von Clarmann, T., Fischer, H., Funke, B., Glatthor, N., Grabowski, U., Kellmann, S., Kiefer, M., Linden, A., Milz, M., Steck, T., Stiller, G. P., Bernath, P., Blom, C. E., Blumenstock, T., Boone, C., Chance, K., Coffey, M. T., Friedl-Vallon, F., Griffith, D., Hannigan, J. W., Hase, F., Jones, N., Jucks, K. W., Keim, C., Kleinert, A., Kouker, W., Liu, G. Y., Mahieu, E., Mellqvist, J., Mikuteit, S., Notholt, J., Oelhaf, H., Piesch, C., Reddmann, T., Ruhnke, R., Schneider, M., Strandberg, A., Toon, G., Walker, K. A., Warneke, T., Wetzel, G., Wood, S., and Zander, R.: Validation of MIPAS $\mathrm{ClONO}_{2}$ measurements, Atmos. Chem. Phys., 7, 257-281, 2007,

http://www.atmos-chem-phys.net/7/257/2007/.

Irie, H., Sugita, T., Nakajima, H., Yokota, T., Oelhaf, H., Wetzel, G., Toon, G. C., Sen, B., Santee, M. L., Terao, Y., Saitoh, N., Ejiri, M. K., Tanaka, T., Kondo, Y., Kanzawa, H., Kobayashi, H., and Sasano, Y.: Validation of stratospheric nitric acid profiles observed by Improved Limb Atmospheric Spectrometer (ILAS)II, J. Geophys. Res., 111, D11S03, doi:10.1029/2005JD006115, 2006.

Kanzawa, H., Sugita, T., Nakajima, H., Bodeker, G. E., Oelhaf, H., Stowasser, M., Wetzel, G., Engel, A., Schmidt, U., Levin, I., Toon, G. C., Sen, B., Blavier, J.-F., Aoki, S., Nakazawa, T., Jucks, K. W., Johnson, D. G., Traub, W. A., Camy-Peyret, C., Payan, S., Jeseck, P., Murata, I., Fukunishi, H., von König, M., Bremer, H., Küllmann, H., Park, J. H., Pan, L. L., Yokota, T., Suzuki, M., Shiotani, M., and Sasano, Y.: Validation and data characteristics of nitrous oxide and methane profiles observed by the Improved Limb Atmospheric Spectrometer (ILAS) and processed with the version 5.20 algorithm, J. Geophys. Res., 108, doi:10.1029/2002JD002458, 2003.

Mengistu Tsidu, G., Stiller, G. P., von Clarmann, T., Funke, B., Höpfner, M., Fischer, H., Glatthor, N., Grabowski, U., Kellmann, S., Kiefer, M., Linden, A., López-Puertas, M., Milz, M., Steck, T., and Wang, D. Y.: $\mathrm{NO}_{y}$ from Michelson Interferometer for Passive Atmospheric Sounding on Environmental Satellite during the Southern Hemisphere polar vortex split in September/October 2002, J. Geophys. Res., 110, D11301, doi: 10.1029/2004JD005322, 2005.

Michelsen, H. A., Manney, G. L., Gunson, M. R., Rinsland, C. P., and Zander, R.: Correlations of stratospheric abundances of $\mathrm{CH}_{4}$ and $\mathrm{N}_{2} \mathrm{O}$ derived from ATMOS measurements, Geophys. Res. Lett., 25, 2777-2780, 1998.

Milz, M., von Clarmann, T., Fischer, H., Glatthor, N., Grabowski, U., Höpfner, M., Kellmann, S., Kiefer, M., Linden, A., Mengistu Tsidu, G., Steck, T., Stiller, G. P., Funke, B., López-Puertas, M., and Koukouli, M. E.: Water Vapor Distributions Measured with the Michelson Interferometer for Passive Atmospheric Sounding on board Envisat (MIPAS/Envisat), J. Geophys. Res., 110, D24307, doi:10.1029/2005JD005973, 2005.

Nakajima, H., Sugita, T., Yokota, T., Kobayashi, H., Sasano, Y.,
Ishigaki, T., Mogi, Y., Araki, N., Waragai, K., Kimura, N., Iwazawa, T., Kuze, A., Tanii, J., Kawasaki, H., Horikawa, M., Togami, T., and Uemura, N.: Characteristics and performance of the Improved Limb Atmospheric Spectrometer-II (ILAS-II) on board the ADEOS-II satellite, J. Geophys. Res., 111, D11S01, doi:10.1029/2005JD006334, 2006a.

Nakajima, H., Sugita, T., Irie, H., Saitoh, N., Kanzawa, H., Oelhaf, H., Wetzel, G., Toon, G. C., Sen, B., Blavier, J.-F., Traub, W. A., Jucks, K., Johnson, D. G., Yokota, T., and Sasano, Y.: Measurements of $\mathrm{ClONO} 2$ by the Improved Limb Atmospheric Spectrometer (ILAS) in high-latitude stratosphere: New products using version 6.1 data processing algorithm, J. Geophys. Res., 111, D11S09, doi:10.1029/2005JD006441, 2006b.

Nash, E. R., Newman, P. A., Rosenfield, J. E., and Schoeberl, M. R.: An objective determination of the polar vortex using Ertel's potential vorticity, J. Geophys. Res., 101, 9471-9478, 1996.

Oshchepkov, S., Sasano, Y., Yokota, T., Nakajima, H., Uemura, N., Saitoh, N., Sugita, T., and Matsuda, H.: ILAS data processing for stratospheric gas and aerosol retrievals with aerosol physical modeling: Methodology and validation of gas retrievals, J. Geophys. Res., 111, D02307, doi:10.1029/2005JD006543, 2006.

Ridolfi, M., Carli, B., Carlotti, M., von Clarmann, T., Dinelli, B., Dudhia, A., Flaud, J.-M., Höpfner, M., Morris, P. E., Raspollini, P., Stiller, G., and Wells, R. J.: Optimized Forward and Retrieval Scheme for MIPAS Near-Real-Time Data Processing, Appl. Opt., 39, 1323-1340, 2000.

Rothman, L. S., Barbe, A., Benner, D. C., Brown, L. R., CamyPeyret, C., Carleer, M. R., Chance, K., Clerbaux, C., Dana, V., Devi, V. M., Fayt, A., Flaud, J.-M., Gamache, R. R., Goldman, A., Jacquemart, D., Jucks, K. W., Lafferty, W. J., Mandin, J.Y., Massie, S. T., Nemtchinov, V., Newnham, D. A., Perrin, A., Rinsland, C. P., Schroeder, J., Smith, K. M., Smith, M. A. H., Tang, K., Toth, R. A., Auwera, J. V., Varanasi, P., and Yoshino, K.: The HITRAN Molecular Spectroscopic Database: Edition of 2000 Including Updates through 2001, HITRAN Special Issue: J. Quant. Spectrosc. Radiat. Transfer, 82, 5-44, 2003.

Rothman, L. S., Jacquemart, D., Barbe, A., Benner, D. C., Birk, M., Brown, L. R., Carleer, M. R., Chackerian Jr., C., Chance, K., Coudert, L., Dana, V., Devi, V. M., Flaud, J.-M., Gamache, R. R., Goldman, A., Hartmann, J.-M., Jucks, K. W., Maki, A. G., Mandin, J.-Y., Massie, S. T., Orphal, J., Perrin, A., Rinsland, C. P., Smith, M. A. H., Tennyson, J., Tolchenov, R. N., Toth, R. A., Auwera, J. V., Varanasi, P., and Wagner, G.: The HITRAN 2004 Molecular Spectroscopic Database, HITRAN Special Issue: J. Quant. Spectrosc. Radiat. Transfer, 96, 139-204, 2005.

Steck, T., von Clarmann, T., Fischer, H., Funke, B., Glatthor, N., Grabowski, U., Höpfner, M., Kellmann, S., Kiefer, M., Linden, A., Milz, M., Stiller, G. P., Wang, D. Y., Alaart, M., Blumenstock, T., von der Gathen, P., Hansen, G., Hase, F., Hochschild, G., G.Kopp, Kyrö, E., Oelhaf, H., Raffalski, U., Redondas Marrero, A., Remsberg, E., Russell III, J., Stebel, K., Steinbrecht, W., Wetzel, G., Yela, M., and Zhang, G.: Bias determination and precision validation of ozone profiles from MIPAS-Envisat retrieved with the IMK-IAA processor, Atmos. Chem. Phys., 7, 3639-3662, 2007,

http://www.atmos-chem-phys.net/7/3639/2007/.

Stiller, G. P. (Ed.): The Karlsruhe Optimized and Precise Radiative Transfer Algorithm (KOPRA), Forschungszentrum Karlsruhe, Wissenschaftliche Berichte, FZKA 6487, 2000. 
Stiller, G. P., Höpfner, M., Kuntz, M., von Clarmann, T., Echle, G., Fischer, H., Funke, B., Glatthor, N., Hase, F., Kemnitzer, H., and Zorn, S.: The Karlsruhe optimized and precise radiative transfer algorithm. Part I: Requirements, justification, and model error estimation, in: Optical Remote Sensing of the Atmosphere and Clouds, Beijing, China, 15-17 September 1998, edited by: Wang, J., Wu, B., Ogawa, T., and Guan, Z., Vol. 3501, 257-268, 1998.

Stiller, G. P., Mengistu Tsidu, G., von Clarmann, T., Glatthor, N., Höpfner, M., Kellmann, S., Linden, A., Ruhnke, R., Fischer, H., López-Puertas, M., Funke, B., and Gil-López, S.: An enhanced $\mathrm{HNO}_{3}$ second maximum in the Antarctic mid-winter upper stratosphere 2003, J. Geophys. Res., 110, D20303, doi: 10.1029/2005JD006011, 2005.

Strong, K., Wolff, M. A., Kerzenmacher, T. E., Walker, K. A., Bernath, P. F., Blumenstock, T., Boone, C., Catoire, V., Coffey, M., De Mazière, M., Demoulin, P., Duchatelet, P., Dupuy, E., Hannigan, J., Höpfner, M., Glatthor, N., Griffith, D. W. T., Jin, J. J., Jones, N., Jucks, K., Kuellmann, H., Kuttippurath, J., Lambert, A., Mahieu, E., McConnell, J. C., Mellqvist, J., Mikuteit, S., Murtagh, D. P., Notholt, J., Piccolo, C., Robert, C., Schneider, M., Schrems, O., Semeniuk, K., Senten, C., Stiller, G. P., Strandberg, A., Taylor, J., Tétard, C., Toohey, M., Urban, J., Warneke, T., and Wood, S.: Validation of ACE-FTS N2O measurements, Atmos. Chem. Phys. Discuss, accepted, 2008.

Sugita, T., Nakajima, H., Yokota, T., Kanzawa, H., Gernandt, H., Herber, A., von der Gathen, P., Koenig-Langlo, G., Sato, K., Dorokhov, V., Yushukov, V. A., Murayama, Y., Yamamori, M., Godin-Beekmann, S., Goutail, F., Roscoe, H., Deshler, T., Yela, M., Taalas, P., Kyro, E., Oltmans, S., Johnson, B., Allaart, M., Litynska, Z., Klekociuk, A., Andersen, S. B., Braathen, G., De Backer, H., Randall, C. E., Thomason, L. W., Irie, H., Ejiri, M. K., Saitoh, N., Tanaka, T., Terao, Y., Kobayashi, H., and Sasano, Y.: Ozone profiles in the high-latitude stratosphere and lower mesosphere measured by the Improved Limb Atmospheric Spectrometer (ILAS)-II: Comparison with other satellite sensors and ozonesondes, J. Geophys. Res., 111, D11S02, doi: 10.1029/2005JD006439, 2006.

Tanaka, T., Nakajima, H., Sugita, T., Ejiri, M. K., Irie, H. Saitoh, N., Terao, Y., Kawasaki, H., Usami, M., Yokota, T., Kobayashi, H., and Sasano, Y.: Tangent height registration method for the Version 1.4 data retrieval algorithm of the solar occultation sensor ILAS-II, Appl. Opt., 46, 7196-7201, 2007.

Verronen, P., Kyrölä, E., Funke, B., Gil-López, S., Kaufmann, M., López-Puertas, M., von Clarmann, T., Stiller, G., Grabowski, U., and Höpfner, M.: A Comparison of night-time GOMOS and MIPAS vertical ozone profiles in the stratosphere and mesosphere, Adv. Space Res., 36, 958-966, 2005.

von Clarmann, T.: Validation of remotely sensed profiles of atmospheric state variables: strategies and terminology, Atmos. Chem. Phys., 6, 4311-4320, 2006,

http://www.atmos-chem-phys.net/6/4311/2006/. von Clarmann, T., Chidiezie Chineke, T., Fischer, H., Funke, B., García-Comas, M., Gil-López, S., Glatthor, N., Grabowski, U., Höpfner, M., Kellmann, S., Kiefer, M., Linden, A., LópezPuertas, M., López-Valverde, M. Á., Mengistu Tsidu, G., Milz, M., Steck, T., and Stiller, G. P.: Remote Sensing of the Middle Atmosphere with MIPAS, in: Remote Sensing of Clouds and the Atmosphere VII, edited by: Schäfer, K., Lado-Bordowsky, O., Comerón, A., and Picard, R. H., SPIE, Bellingham, WA, USA, Vol. 4882, 172-183, 2003a.

von Clarmann, T., Glatthor, N., Grabowski, U., Höpfner, M., Kellmann, S., Kiefer, M., Linden, A., Mengistu Tsidu, G., Milz, M., Steck, T., Stiller, G. P., Wang, D. Y., Fischer, H., Funke, B., Gil-López, S., and López-Puertas, M.: Retrieval of temperature and tangent altitude pointing from limb emission spectra recorded from space by the Michelson Interferometer for Passive Atmospheric Sounding (MIPAS), J. Geophys. Res., 108, 4736, doi:10.1029/2003JD003602, 2003b.

Wang, D.-Y., Stiller, G. P., von Clarmann, T., Fischer, H., Glatthor, N., Grabowski, U., Höpfner, M., Kellmann, S., Kiefer, M., Linden, A., Mengistu Tsidu, G., Milz, M., Steck, T., Wohnsiedler, S., López-Puertas, M., Funke, B., Gil-López, S., Kaufmann, M., Koukouli, M., Murtagh, D., Lautie, N., Jimenez, C., Jones, A., Eriksson, P., Urban, J., Noe, J., Flochmoen, E., Dupuy, E., Ricaud, P., Olberg, M., Frisk, U., Russel III, J., and Remsberg, E.: Comparisons of MIPAS/SAT ozone profiles with SMR/ODIN and HALOE/UARS observations, Adv. Space Res., 36, 927-931, 2005.

Wang, D. Y., Höpfner, M., Mengistu Tsidu, G., Stiller, G. P., von Clarmann, T., Fischer, H., Blumenstock, T., Glatthor, N., Grabowski, U., Hase, F., Kellmann, S., Linden, A., Milz, M., Oelhaf, H., Schneider, M., Steck, T., Wetzel, G., López-Puertas, M., Funke, B., Koukouli, M. E., Nakajima, H., Sugita, T., Irie, H., Urban, J., Murtagh, D., Santee, M. L., Toon, G., Gunson, M. R., Irion, F. W., Boone, C. D., Walker, K., and Bernath, P. F.: Validation of nitric acid retrieved by the IMK-IAA processor from MIPAS/ENVISAT measurements, Atmos. Chem. Phys., 7, 721-738, 2007,

http://www.atmos-chem-phys.net/7/721/2007/.

Wetzel, G., Oelhaf, H., Friedl-Vallon, F., Kleinert, A., Lengel, A., Maucher, G., Nordmeyer, H., Ruhnke, R., Nakajima, H., Sasano, Y., Sugita, T., and Yokota, T.: Intercomparison and validation of ILAS-II version 1.4 target parameters with MIPASB measurements, J. Geophys. Res., 111, D11S06, doi:10.1029/ 2005JD006287, 2006.

Yokota, T., Nakajima, H., Sugita, T., Tsubaki, H., Itou, Y., Kaji, M., Suzuki, M., Kanzawa, H., Park, J. H., and Sasano, Y.: Improved Limb Atmospheric Spectrometer (ILAS) data retrieval algorithm for Version 5.20 gas profile products, J. Geophys. Res., 107, 8216, doi:10.1029/2001JD000628, 2002. 